\title{
Creditor rights and the outcome model of dividends $s^{\text {th }}$
}

\author{
Julie Byrne, Thomas O’Connor* \\ Department of Economics, Finance and Accounting, National University of Ireland Maynooth, Maynooth, Co. Kildare, Ireland
}

\section{A R T I C L E I N F O}

\section{Article history}

Received 23 May 2011

Received in revised form

19 December 2011

Accepted 6 April 2012

Available online 21 April 2012

\section{JEL classification:}

G15

G35

Keywords:

Dividend policy

Creditor rights

Shareholder rights

Corporate governance

\begin{abstract}
A B S T R A C T
Using a sample of 22,374 firms from 35 countries, we examine the role of creditor rights, shareholder rights, and corporate governance in determining corporate dividend policy. We find that, while all three variables play a significant role in determining both the likelihood and the dividend amount, the effect of country-level creditor rights dominate. In subsequent analysis, we show that the outcome model is most effective in countries with strong creditor rights. When creditor rights are weak, creditors demand, and firms consent to lower dividends. These findings show that creditors, and not shareholders, exert the greatest influence over corporate dividend policy.
\end{abstract}

(C) 2012 The Board of Trustees of the University of Illinois. Published by Elsevier B.V. All rights reserved.

\section{Introduction}

La Porta, Lopez-de-Silanes, Shleifer, and Vishny (2000), and more recently Brockman and Unlu (2009), show how corporate dividend policy is influenced by the strength of the legal rights afforded to the providers of external capital to corporations. The former relate shareholder rights, measured at the country-level to corporate dividend payout, and test two competing agency models of dividends, namely the outcome and substitution models. The outcome model, built on Jensen's (1986) free cash flow hypothesis suggests that shareholders can exercise their legal rights to force firms to pay dividends, in turn reducing the agency costs associated with free cash flow. The ability of shareholders to extract dividends from firms increases in the strength of their legal rights. Hence, dividends are an outcome of shareholder rights; the likelihood of paying a dividend, and the dividend amount increase in the strength of shareholder rights. The substitution model suggests otherwise. Under the predictions of the substitution model, firms use dividends as a bonding device. Firms substitute poor

\footnotetext{
The paper was previously circulated under the heading "Shareholder and creditor legal rights and the outcome model of dividends". We thank an anonymous referee for helpful comments on an earlier version of the paper. We accept responsibility for any remaining errors.

* Corresponding author.

E-mail address: thomas.g.oconnor@nuim.ie (T. O’Connor).
}

shareholder rights for high dividends. In doing so, firms establish a reputation for fair treatment of their minority shareholders, which in turn should lower their cost of capital, and relax their financing constraints. As a result, the incidence of paying a dividend, and the amount of the dividend paid should decrease in the strength of shareholder rights, since firms with the most severe agency problems are more likely to pay higher dividends. ${ }^{1}$ La Porta et al. (2000) find support in favor of the outcome model of dividends; dividend payout increases in the level of shareholder rights. Subsequent work also shows that shareholder rights, but now measured at the firm-level (i.e., corporate governance) also

\footnotetext{
${ }^{1}$ In recent work, Chae, Kim, and Lee (2009) show that total payout (dividends and share repurchases) is higher in firms where corporate governance is strong and when external financing costs are low (and/or when there is no need for external financing). When corporate governance is strong, but sizable external financing constraints exist, total payout tends to be much lower. Their findings suggest that in determining payout policy, managers balance the benefit of paying dividends, i.e., a reduction in the agency costs of free cash flow a la Jensen (1986) against the costs of external financing. Their results are thus in line with Rozeff (1982). This line of reasoning would then suggest that the tendency on the part of firms with sizable agency costs to pay higher dividends is likely to be very much a function of the joint effect of agency costs and their external financing need. Firms with sizable agency costs and external financing costs are more likely to pay higher dividends according to the substitution hypothesis. Mansi and Wald (2010) highlight the prevalence of dividends as a bonding mechanism to guard against the free cash flow problem when firms face limitations on the use of debt, and when managerial ownership is low.
} 
influences corporate dividend policy. With some exceptions, much of the empirical evidence finds support in favor of the outcome model (Bartram, Brown, How, \& Verhoeven, 2008; Jiraporn, Kim, \& Kim, 2011; Mitton, 2004); the likelihood of paying a dividend, and the dividend amount tends to increase in the strength of shareholder rights, i.e., corporate governance. ${ }^{2}$ In turn, in an emerging market setting, Mitton (2004) shows that while shareholder rights measured at the country- and firm-level both influence corporate dividend payout, the country effect dominates. Furthermore, he finds that they tend to complement one another, resulting in higher dividend payouts where country and corporate governance are strong. More recent work explores the link between creditor rights, shareholder rights (only measured at the country-level), and corporate dividend payout. Brockman and Unlu (2009) show that the likelihood of paying a dividend and the dividend amount increase in both shareholder and creditor rights. However, the latter effect dominates.

In this paper, we explore an issue left unresolved given the findings of La Porta et al. (2000), and Brockman and Unlu (2009). ${ }^{3}$ It is as follows. We examine whether shareholders are, through their legal rights measured at the country- and firm-level, better able to extract larger dividends from firms, even when creditors are likely to demand otherwise. Creditors are likely to demand otherwise when their legal rights are weak. Brockman and Unlu (2009) suggest that creditors and not shareholders exert the greatest influence over corporate dividend payout. Hence, if creditors do in fact exert the greatest influence over corporate dividend payout as Brockman and Unlu (2009) suggest they do, then the likelihood of, and the dividend amount is likely to be much lower given poor creditor rights, even when shareholder rights are strong. This suggests that the ability of shareholders with strong legal rights to extract dividends from firms is diminished when creditor rights are weak. In other words, a priori, we expect that the outcome model of dividends be much less relevant given poor creditor protection. In this paper, we test this proposition.

To do so, we form a panel of 22,374 firms from 35 countries to test the legitimacy of the outcome model of dividends by examining the influence of creditor and shareholder rights, with the latter measured at both the firm- (corporate governance) and countrylevel on corporate dividend payout policy. In a series of pooled logit and Tobit regressions, we show that while creditor rights, shareholder rights and corporate governance all influence both the level and likelihood of dividend payouts, creditors exert the

\footnotetext{
2 Jiraporn and Ning (2006), Chae et al. (2009), and Mitton (2004) in civil law countries only, all find support in favour of the substitution model of dividends. Both Jiraporn and Ning (2006) and Chae et al. (2009) use a sample of firms from the U.S. Mitton (2004) uses a sample of emerging market firms. Sawicki (2009) finds support in favour of the substitute model in Asia pre-Asian crisis, and the outcome model post-crisis. Interestingly, using the G-Index of Gompers, Ishii, and Metrick (2003) to measure the strength of corporate governance of U.S. firms, Jiraporn and Ning (2006) find in favour of the substitution model. Again using U.S. firms, but now using governance data from the Institutional Shareholder Services (ISS), Jiraporn et al. (2011) find in favour of the outcome model. The ISS data is a much broader corporate governance measure than the G-Index, which in turn, likely explains the conflicting findings. Brockman and Unlu (2011) show that the substitution model prevails in countries where disclosure environments are opaque and the outcome model in countries where disclosure environments are transparent.

${ }^{3}$ A second fundamental question that arises, but which we do not examine in this paper relates to instances in which shareholders are not well-protected, but creditors are. Brockman and Unlu (2009) show that dividend payout increases in both creditor and shareholder protection. However, what we do not know is whether creditors force firms to pay higher dividends (i.e., when creditor rights are strong) when shareholder rights are weak. In unreported results, we show that creditors do not use their legal rights to force firms to pay higher dividends when shareholder rights are weak. These findings are available from the corresponding author upon request. In closely related work, Shao et al. (2009) explore this issue in great detail in their paper.
}

greatest influence. This finding is in line with Brockman and Unlu (2009). Next, and consistent with Mitton (2004), we find that shareholder rights measured both at the firm- and country-level influence corporate dividend payout, with the latter country-effect again dominating. In turn, we show that both shareholder rights measures still matter, and the same hierarchy is maintained, even with the inclusion of creditor rights. However, when all three measures are included simultaneously, the effect of creditor rights dominates. ${ }^{4}$ Second, and different to both Mitton (2004) and Brockman and Unlu (2009), we repeat our initial analysis, but now by level of creditor rights. Our findings are in line with our prior expectations. We find that the outcome model is most effective in countries with strong creditor rights. We find that the coefficient estimates on the shareholder rights measures (i.e., firm- and country-level), are positive, large, and invariably statistically significant, when creditor rights are strong. In contrast, where creditor rights are weak, the coefficient estimates on the shareholder rights measures are much lower, surprisingly sometimes negative, and at times statistically insignificant. Our findings suggest that the outcome model of dividends is much less relevant under poor creditor rights. When creditors are poorly protected, they demand and firms consent to lower dividends. In effect, creditors substitute poor legal standing with lower dividends.

These findings serve to reinforce the conclusions reached by Brockman and Unlu (2009). Creditors exert a much greater influence on dividend payout policy than do shareholders. The likelihood of, and the dividend amount are much lower when creditor rights are weak, regardless of the strength of shareholder rights. Furthermore, and in addition to the findings of Brockman and Unlu (2009), we show that creditor rights dominate shareholder rights, even when shareholder rights are measured at the firm- and country-level. In this regard, neither firm nor country-level shareholder rights are able to dominate creditor rights. Furthermore, we find that while the outcome model remains relevant under poor creditor rights when shareholder rights are measured at the firmlevel, the substitute model prevails when shareholder rights are measured at the country-level. This latter finding suggests that when creditor rights are weak, dividend payouts decrease with country-level shareholder rights. Our analysis suggests that the findings of La Porta et al. (2000), and Mitton (2004), which do not account for the strength of creditor rights, are in retrospect, largely contingent on both shareholders and creditors enjoying substantial legal rights. When the latter are not well-protected under the legal regime, the number of firms paying dividends, and the dividend amounts are much lower.

Finally, in a series of robustness tests, we show that our results are not sensitive to our measure of corporate governance. We extend the analysis originally undertaken by Mitton (2004). Using Credit Lyonnais Securities Asia (CLSA, 2001) corporate governance data for 304 emerging market firms, we show that the ability of shareholders to extract dividends from firms using their firmlevel legal rights is contingent on strong shareholder and creditor rights. ${ }^{5}$ When creditors do not enjoy sizable legal rights, the outcome model of dividends becomes less relevant, irrespective of the strength of shareholder rights. The likelihood and the dividend amount are highest when both shareholders and creditors enjoy sizable legal rights.

Our work extends the literature in a number of ways. First, our findings serve to reinforce the findings of Brockman and Unlu (2009), and demonstrate the persuasive effect that creditors have

\footnotetext{
${ }^{4}$ The exceptions occur when we use different measures of country-level share holder rights. We return to this issue in much greater detail later in the paper.

${ }^{5}$ Our sample size is not identical to that of Mitton (2004), but less than his.
} 
on corporate dividend policy. Irrespective of the source of their legal rights (i.e., firm- or country-level), shareholders exert much less of an influence over dividend policy than do creditors. When creditors do not enjoy sizable legal rights, they demand, and firms cater to lower dividend payouts. This finding is in line with a large volume of recent literature which highlights the influence of creditors in corporate finance decisions. ${ }^{6}$ For example, creditors restrict firm-level investment (capital expenditures) when borrower credit quality deteriorates (see Nini, Smith, \& Sufi, 2009). In turn, Roberts and Sufi (2009) show that the ability of firms to finance firm-level investment using debt financing is significantly reduced following debt covenant violations. Second, we show that creditors exert greater influence over firm- and countrylevel shareholder rights. Our paper is most closely related to that of concurrent work undertaken by Shao, Kwok, and Guedhami (2009), but differs in that we also include a measure for firm-specific shareholder rights (corporate governance). Unlike them, we show that the ability of shareholders to extract large dividends from firms, when shareholder rights are measured at the firm- (corporate) and country-level, is largely diminished when creditor rights are weak. Their focus is solely on country-level shareholder rights.

Finally, our work also contributes to the large literature which focuses on the factors that influence corporate dividend payout policy. For example, the most recent work highlights the importance of a firm's life-cycle, and cash-flow uncertainty in determining the likelihood of paying dividends, and the dividend amount (Brockman \& Unlu, 2011; Chay \& Suh, 2009; DeAngelo, DeAngelo, \& Stulz, 2006; Denis \& Osobov, 2008; Grullon, Michaely, \& Swaminathan, 2002). Specifically, Grullon et al.(2002), DeAngelo, DeAngelo, and Stulz (2006), Denis and Osobov (2008), and most recently Brockman and Unlu (2011) all highlight the importance of the earned/contributed capital mix and corporate dividend policy. ${ }^{7}$ Mature firms (i.e., with a high earned to total capital ratio) initiate and pay dividends, younger firms, typically with a small earned to total capital ratio do not. Hence, the likelihood of, and the dividend amount increase in the ratio of earned to total capital. In a similar vein, Chay and Suh (2009) highlight the influence of cashflow volatility on corporate dividend policy; the likelihood of paying a dividend and the size of the dividend is inversely related to cashflow volatility. In turn, they show that the effect of cashflow volatility on dividend policy is independent of the life-cycle effect; mature firms with highly volatile cashflow are, all else equal, less likely to pay a dividend. In this paper, we show that when creditor rights are weak, the number of dividend payers, and the size of the dividend is much lower, irrespective of the strength of shareholder rights.

The paper proceeds as follows. In Section 2, we discuss our data. We present and discuss our empirical findings in Section 3. Section 4 concludes.

\section{Data and variable description}

We test the validity of the outcome model of dividends using creditor rights and shareholder rights. Our approach differs from

\footnotetext{
${ }^{6}$ In addition, Acharya, Amihud, and Litov (2009) find that stronger creditor rights reduce corporate risk-taking. In contrast, using a sample of almost 2400 banks, Houston, Lin, and Ma (2010) find to the contrary; stronger creditor rights serve to promote greater bank risk-taking. Benmelech and Bergman (2011) explore the relationship between the strength of creditor rights and firm-level investment in the airline industry. They find that better creditor rights are associated with firms having younger more technologically advanced aircraft, and with larger fleet.

7 The earned/contributed capital mix is also referred to as the life-cycle model of dividends. Grullon et al. (2002) and DeAngelo et al. (2006) find support in favour of the life-cycle model using U.S. firms. Brockman and Unlu (2011) and Denis and Osobov (2008) do likewise using U.S. and international firms.
}

previous studies in that we examine the effect not only of shareholder rights at the country-level, but also at the firm-level. We begin our study by consulting the country files from Worldscope over the period from 1980 to 2007. From this original sample of countries, we follow La Porta et al. (2000) and eliminate firms trading in socialist countries, i.e., China, Poland, and Hungary, firms trading in Luxembourg, and firms with mandatory dividend policies, i.e., Brazil, Chile, Colombia, Greece, and Venezuela. In turn, we eliminate all financial and utility firms using the general industry classification codes from Worldscope (Worldscope Field 06010), and firm-years with missing or abnormal data, i.e., firms with negative net income, negative total assets, and negative cashflow. ${ }^{8}$ Finally, we require all firms to have at least three years of financial data over the entire sample period. After imposing these data requirements, we lose all firms from Jordan, Peru, Philippines, Sri Lanka, and Zimbabwe. This leaves 22,374 firms from 35 countries, namely Argentina, Australia, Austria, Belgium, Canada, Denmark, Egypt, Finland, France, Germany, Hong Kong, India, Indonesia, Ireland, Israel, Italy, Japan, Korea (Republic), Malaysia, Mexico, Netherlands, New Zealand, Norway, Pakistan, Portugal, Singapore, South Africa, Spain, Sweden, Switzerland, Taiwan, Thailand, Turkey, United Kingdom and the United States. The final sample covers the years from 1991 to 2007.

Using this sample of 35 countries, we source data on shareholder and creditor rights. We use five distinct measures of shareholder rights, namely the revised anti-director rights measure, the antiself-dealing index, rule of law, legality, and investor protection. The revised anti-director rights measure is sourced from Djankov, LaPorta, Lopez-de-Silanes, and Shleifer (2008), and is a revised version of the original anti-director rights measure of La Porta, Lopez-de-Silanes, Shleifer, and Vishny (1998). The anti-self-dealing index is also sourced from Djankov et al. (2008). This measure captures the extent to which outsiders are protected from selfdealing (expropriation) by controlling insiders. Higher values of the index imply that outsiders are less likely to be expropriated by insiders, and thus imply greater protection. Legality is an aggregate index measuring the strength of the legal environment. It is constructed as the weighted average of five separate components, namely judicial efficiency, rule of law, corruption, risk of expropriation, and risk of contract repudiation as originally constructed by Berkowitz, Pistor, and Richard (2003). ${ }^{9}$ Investor Protection is taken from La Porta, Lopez-de-Silanes, and Shleifer (2006) and is calculated as the weighted average of disclosure, liability standards, and (original) anti-director rights, again using principal component analysis. Investor protection ranges from a low of zero to a high of ten, where higher values correspond to better levels of investor protection. The rule of law variable sourced from La Porta et al. (1998) ranges from zero to ten, where higher values imply greater legal development. The creditor rights measure is taken from Djankov, McLeish, and Shleifer (2007), and ranges from a low of zero to a high of four, where higher values represent greater levels of creditor protection. Panel B of Table 1 presents, by country, each measure of shareholder and creditor rights. In Appendix 1, we shed further light on the relationships between these measures by presenting some correlation estimates. Panel B and Appendix 1 suggest the following. Without exception, each of the five shareholder rights measures is positively correlated with creditor rights, which

\footnotetext{
${ }^{8}$ The general industry classification codes are (1) industrial, (2) utility, (3) transportation, (4) bank/savings and loan, (5) insurance, and (6) other financial.

${ }^{9}$ Berkowitz et al. (2003) derive the legality index using principal components analysis. The weights are assigned as follows: legality $=0.381^{*}$ (judicial efficiency) $+0.503^{*}$ (rule of law $)+0.503^{*}$ (corruption $)+0.347^{*}$ (risk of expropriation $)+0.384^{*}$ (risk of repudiation) .
} 
Table 1

Sample description. This table reports summary statistics for the entire sample. Panel A reports by country, the number of firm-year observations (\#Obs), the number of firms (\#Firms), the number of dividend payers (\#Dividend Payers), the percentage of firms in each country that pay a dividend at any point in the sample period (\%Dividend Payers), and the average dividend payout in each country. Dividend payout is measured as dividends to cashflow (\%). Dividend payer equals one if the firm pays a dividend. In the remaining columns of Panel A, we outline, by country, the average and standard deviation of agency costs. Corporate governance is calculated as sales-to-total assets. All information on payout ratios and corporate governance is sourced from Worldscope. Panel B displays shareholder and creditor rights data by country. Revised ADR and the anti-self-dealing index (ASD) are shareholder rights measures from Djankov et al. (2008). Legality is an index of legal development and is measured as the weighted average of judicial efficiency, rule of law, corruption, risk of expropriation, and risk of contract repudiation (Berkowitz et al., 2003). Investor Protection is from La Porta et al. (2006) and is calculated as the weighted average of disclosure, liability standards, and anti-director rights. Rule of law is from La Porta et al. (1998). Creditor Rights is from Djankov et al. (2007).

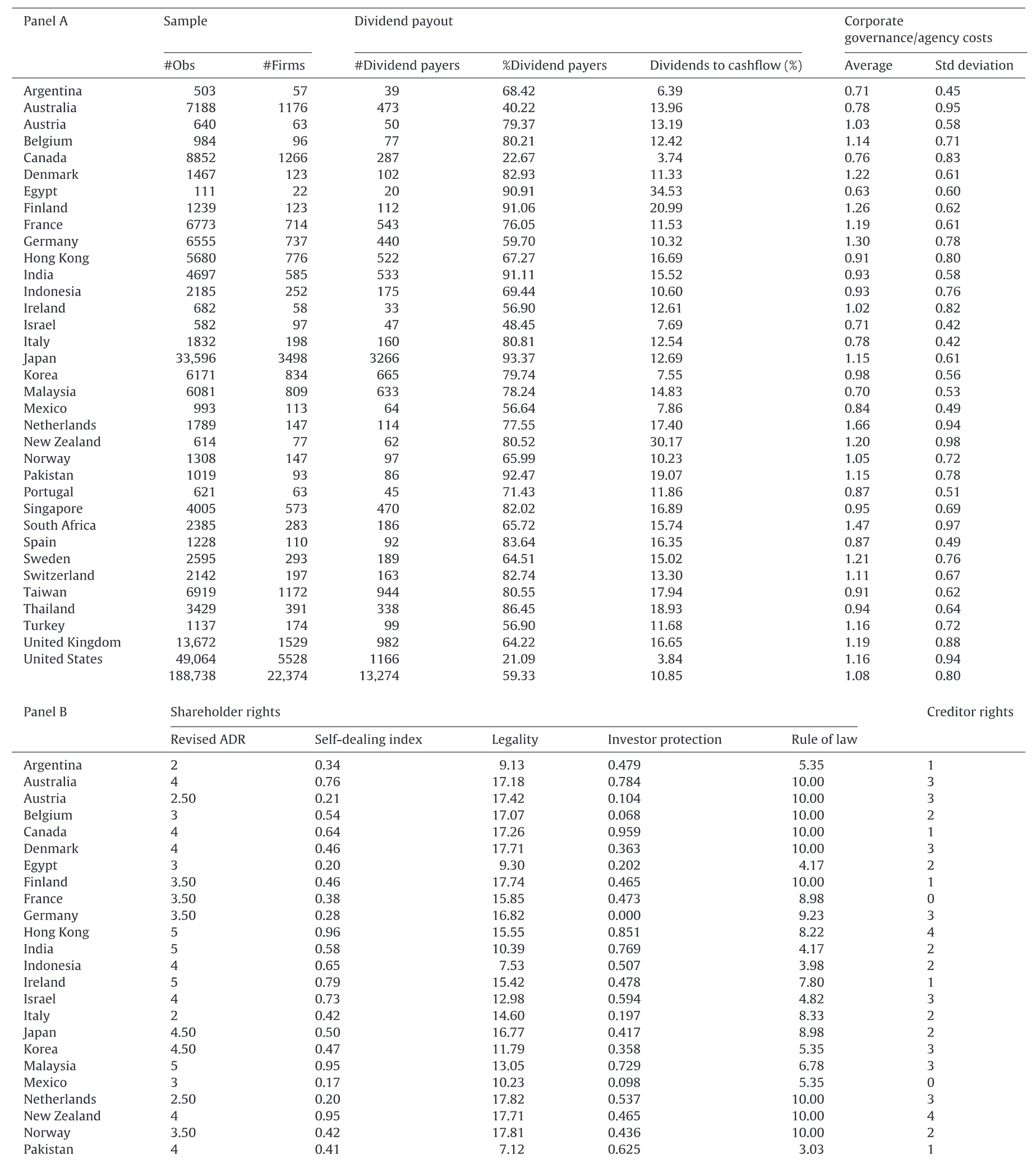


Table 1 (Continued)

\begin{tabular}{|c|c|c|c|c|c|c|}
\hline \multirow[t]{2}{*}{ Panel B } & \multicolumn{5}{|c|}{ Shareholder rights } & \multirow[t]{2}{*}{ Creditor rights } \\
\hline & Revised ADR & Self-dealing index & Legality & Investor protection & Rule of law & \\
\hline Portugal & 2.50 & 0.44 & 14.20 & 0.574 & 8.68 & 1 \\
\hline Singapore & 5 & 1.00 & 16.65 & 0.770 & 8.57 & 3 \\
\hline South Africa & 5 & 0.81 & 10.27 & 0.599 & 4.42 & 3 \\
\hline Spain & 5 & 0.37 & 14.25 & 0.553 & 7.80 & 2 \\
\hline Sweden & 3.50 & 0.33 & 17.78 & 0.386 & 10.00 & 1 \\
\hline Switzerland & 3 & 0.27 & 18.00 & 0.304 & 10.00 & 1 \\
\hline Taiwan & 3 & 0.56 & 14.54 & 0.547 & 8.52 & 2 \\
\hline Thailand & 4 & 0.81 & 10.16 & 0.373 & 6.25 & 2 \\
\hline Turkey & 3 & 0.43 & 9.08 & 0.338 & 5.18 & 2 \\
\hline United Kingdom & 5 & 0.95 & 16.92 & 0.776 & 8.57 & 4 \\
\hline United States & 3 & 0.65 & 17.40 & 1.000 & 10.00 & 1 \\
\hline Medians & 4 & 0.47 & 15.55 & 0.48 & 8.57 & 2 \\
\hline
\end{tabular}

suggests that in countries, where shareholders are well protected, so too are creditors. However, the correlations are small, suggesting that there are exceptions. The most notable exceptions are evident in both Canada and the United States. In both, shareholders tend to enjoy much greater protection than creditors. In both, the creditor rights score is just 1 , compared to an anti-director rights score of 4 in Canada and 3 in the United States. Similar relationships manifest in Mexico (creditor rights is 0 and anti-director rights is 3 ) and Pakistan (creditor rights is 1 and anti-director rights is 4). In this paper, we examine whether shareholders in these countries are able to extract large dividend payouts from firms as the outcome model suggests, in spite of the fact that creditors are poorly protected, and may demand lower dividends as a consequence. A priori, we expect that this may not be the case. Instead, we expect that dividend payouts (the amount and the likelihood of paying a dividend) are likely to be larger in countries where shareholders and creditors are both well protected in law, e.g., in New Zealand (anti-director rights and creditor rights is both 4), and Hong Kong (anti-director rights is 5 and creditor rights is 4 ). In contrast, dividend amounts, and the likelihood of paying a dividend are likely to be smaller in countries where shareholders are well protected, but where creditors are not necessarily so (e.g., Canada). In fact, a casual inspection of the summary payout measures outlined in Table 1 suggests that this is in fact the case. The likelihood and dividend amount is much larger in Hong Kong and New Zealand than in Canada. Later, we examine if this relation still holds when we control for firm, industry and time effects.

Second, the individual measures of shareholder rights are not necessarily positively related to one another. Anti-director rights, anti-self-dealing index, and investor protection tend to be positively correlated with one another. For example, the correlation coefficient between anti-director rights and anti-self-dealing index is 0.676 , and anti-director rights index and investor protection is 0.479 . In turn, the anti-self-dealing index and investor protection are also positively correlated with one another (correlation coefficient is 0.625 ). For example, Hong Kong scores highly in all three measures (anti-director rights is 5 , anti-self-dealing is 0.96 , and investor protection is 0.851 ). Likewise, Italy scores poorly using all three measures (anti-director rights are 2, anti-self-dealing is 0.42 , and investor protection is 0.197 ). There are exceptions. For example, Denmark scores highly using the anti-director rights measures (4), but scores below the sample median using both the anti-self-dealing index and the level of investor protection. Similar observations arise in Korea, and to a lesser degree in Spain. Next, we find that the revised anti-director rights index is negatively correlated with both legality and rule of law. For example, India scores highly using the revised anti-director rights, but much lower using legality and rule of law. Legality and rule of law are effectively measures of how legal rights are enforced in a country.
Hence, in India, strong shareholder rights tend not to be rigorously enforced. The anti-self-dealing index is also negatively correlated with rule of law, and in common with the measure of investor protection, only marginally correlated with the legality measure. These measures have some potentially important implications for our analysis. Most importantly, they suggest that the outcome model of dividends may not hold using different measures of shareholder rights. We return to this issue in much greater detail later.

To measure the strength of corporate governance, we use total (annual) sales divided by total assets, which is a measure of how effectively the firm's assets are deployed to generate (sales) revenue. Ang, Cole, and Lin (2000) theorize that agency costs decrease as this ratio increases, hence the higher this ratio, the bettergoverned the firm. Singh and Davidson (2003), Bartram et al. (2008) (in an earlier version of their paper) and McKnight and Weir (2009) use variants of this agency cost measure in their studies. ${ }^{10}$ In the last two columns of Panel A of Table 1, we report the average and variation (standard deviation) in agency costs in each country. All else equal, agency costs tend to be less severe in, amongst others, the Netherlands, Germany, Denmark, Sweden, and New Zealand. In contrast, they tend to be severe in Argentina and Egypt. The greatest variation in agency costs occurs in Australia and the Netherlands. ${ }^{11}$ Because of potential concerns over our use of this governance proxy, later by way of robustness analysis, we employ the same Credit Lyonnais Securities Asia (CLSA) governance scores as used by Mitton (2004) to quantify the strength of corporate governance for a sample of 304 emerging market firms. ${ }^{12}$ We provide a fuller discussion of these corporate governance scores later.

We use three different dividend payout measures, namely dividends-to-earnings (\%), measured as dividends per share divided by earnings per share and expressed as a percentage, dividends-to-cashflow (\%), measured as dividends per share divided by cashflow per share also expressed as a percentage, and dividends-to-sales (\%), measured as cash dividends (paid to common and preferred shareholders) divided by net sales, again also expressed as a percentage. In this paper our focus is very much on

\footnotetext{
${ }^{10}$ These agency cost proxies are employed as dependent variables (industryadjusted) in the McKnight and Weir (2009) study, while Bartram et al. (2008) employ the ratios as independent variables in corporate total payout regressions.

${ }^{11}$ Klapper and Love (2004) show that the variation in corporate governance ratings (using CLSA corporate governance scores) decreases as country level investor protection increases.

${ }^{12}$ In this paper we, like others (see Mitton, 2004), seek to examine the effect of the overall corporate governance status of the firm on corporate dividend payout policy. Others relate specific aspects of corporate governance to dividend payout. These include managerial/insider ownership (Farinha \& Lopez-de-Foronda, 2009; Hu \& Kumar, 2004; Rozeff, 1982), institutional ownership (Short, Zhang, \& Keasey, 2002), foreign (institutional) ownership (Baba, 2009), ownership/control structures (Renneboog \& Trojanowski, 2007; Setia-Atmaja et al., 2009).
} 
extending the work of both Mitton (2004) and Brockman and Unlu (2009), who examine the effect of shareholders and shareholder and creditor rights on corporate dividend policy (as opposed to total payout policy), respectively. ${ }^{13}$ All data is sourced from Worldscope. The dividend payer variable equals 1 if the firm pays a dividend in each year, and zero otherwise. In all regressions, we control for firm size, firm profitability and firm growth. Size is measured as the log of book assets in US\$, growth is the logarithmic one-year asset growth, and profitability is earnings before interest and taxation (EBIT) to book assets. All firm level variables are winsorized at the 1 st and 99 th percentiles. ${ }^{14}$

Our final sample is presented in Table 1. Panel A of Table 1 reports, by country, the number of firm-year observations (\#Obs), the number of firms (\#Firms), the number of dividend payers (\#Dividend Payers), the percentage of the entire sample of firms (in each country) that pay a dividend (\%Dividend Payers), and the average over the entire sample period dividends-to-cashflow (\%). ${ }^{15}$ We deem a firm a dividend payer if the firm pays a dividend in any year of our sample period. Thus, even if a firm pays a dividend in only one of our sample years, the firm is deemed a dividend payer. In the remaining columns of Panel $\mathrm{A}$, we report the average and standard deviation of agency costs (corporate governance).

The contribution of each country to our final sample varies significantly. Egypt contributes just 111 firm-year observations (corresponding to just 22 firms), while, non-surprisingly, the United States contributes the most (49,064 firm-year observations and 5528 firms). Japan and the United Kingdom also contribute significantly to the final sample. Japan contributes 33,596 firm-year observations (3498 firms), and the United Kingdom 13,672 firmyear observations (1529 firms). Collectively, firms from the United States, Japan, and the United Kingdom contribute 96,332 firm-year observations $(10,555$ firms or $47.18 \%$ of the entire sample of firms).

The number and proportion of dividend payers also varies significantly by country. Again, Japan (3266 dividend payers), the United States (1166), and the United Kingdom (982) contribute the largest number of dividend payers. However, as a proportion of the entire sample in each country, the conclusions are very different. For example, almost all (93.37\% (3266/3498)) Japanese firms pay a dividend at least once over the sample period. Similar proportions are observed in Egypt (90.91\%), Finland (91.06\%), India (91.11\%), Pakistan (92.47\%), and Thailand (86.45\%). In contrast, only $64.22 \%$ (982/1529) pay dividends in the United Kingdom. A much smaller proportion pays dividends in the United States $(21.09 \%$ or $1166 / 5528) .{ }^{16}$ For the entire sample of firms, 13,274 or $59.33 \%$ pay a dividend at some time over the sample period. The amount paid

\footnotetext{
13 Others do concentrate on the agency models of total payout. These include Bartram et al. (2008) and Mansi and Wald (2010).

14 Ideally, we would like to have included some additional controls variables (e.g. retained earnings and total shareholders' equity as per DeAngelo et al. (2006), Denis and Osobov (2008), and Brockman and Unlu (2011). However, we do not have access to these variables, and some others, and thus, our set of control variables is limited to firm size, firm growth and firm profitability. Nonetheless, these are the same set of control variables that Mitton (2004) uses. Furthermore, our findings are in line with those of Shao et al. (2009) who include additional control variables that we cannot. Hence, we feel that it is unlikely that our findings would be affected by the inclusion of additional control variables.

15 Due to space constraints, we do not present the corresponding figures using dividends-to-sales (\%) and dividends-to-earnings (\%). These statistics are available from the corresponding author upon request.

${ }^{16}$ Our proportions for the U.S. are very different to Brockman and Unlu (2009). In their sample, which covers the period from 1990 to $2006,42.8 \%$ of U.S. firms pay a dividend, much larger than the $21.09 \%$ that we report. The explanation for the difference may lie with the databases used. Brockman and Unlu (2009) use Compustat, while we use Worldscope. The latter suffers from sample bias. Worldscope began its coverage with large firms, and over time expanded to include small firms. Smaller, less profitable, and/or fact growing companies typically pay little or no dividends
}

in dividends (relative to cashflow) also varies across countries. All else equal, dividend amounts are largest in Egypt (34.53\%), and New Zealand (30.17\%). Interestingly, in two countries where creditors enjoy much less legal protection than shareholders dividend payouts tends to be much smaller. Median dividend payouts are just $3.74 \%$ and $3.84 \%$ in Canada and the United States, respectively. The payout statistics imply that, all else equal, creditors influence corporate dividend payout, by mandating lower dividend payouts. In this regard, lower dividend payouts substitute for poor creditor rights.

Finally, Appendix 1 contains correlation estimates using all of the main variables employed in the analysis. The firm-level control variables are excluded, but are related to each of the dividend payout measures as theory predicts, i.e., consistent with the lifecycle model of dividends, large, profitable, and slow growing firms pay higher dividends (DeAngelo et al., 2006; Denis \& Osobov, 2008). The correlation coefficients suggest that, all else equal, the relationship between dividend payout and shareholder rights is contingent on how we measure shareholder rights at the country level. Dividend amounts increase in shareholder rights, when we use the revised anti-director rights and the anti-self-dealing index to measure shareholder rights. In contrast, using the other three measures of shareholder rights, the substitute model holds, namely dividend payouts decrease in shareholder rights. This is not surprising, since we found earlier that not all of these country-level measures of shareholder protection are positively correlated. Finally, corporate governance (using the ratio of sales-to-assets) tends to be positively correlated with dividend payouts, a finding in line with Mitton (2004), Bartram et al. (2008), and more recently Adjaoud and Ben-Amar (2010), and Jiraporn et al. (2011). ${ }^{17}$

\section{Empirical findings}

\subsection{Summary statistics}

We begin our analysis by presenting summary payout statistics by level of shareholder and creditor rights. They are reported in Table 2. We present three separate sets of summary statistics. In Panel A of Table 2, we present average and median payout ratios by level of shareholder rights. A firm belongs in the high shareholder rights grouping if it is domiciled in a country with above-median shareholder rights. The median figures are country (sample) medians. Here shareholder rights are measured at the country-level, and each of the five different measures of shareholder rights are used, namely the revised anti-director rights, the anti-self-dealing index, investor protection, legality, and the rule of law. Dividend payout is calculated using dividends-to-cashflow (\%). ${ }^{18}$

A priori, we expect that, all else equal, if the outcome model holds, firms in countries with high shareholder rights pay higher dividends. When the revised anti-director rights index is used to measure shareholder rights, we find support in favor of the outcome model. Firms in countries where shareholders are wellprotected (revised $A D R \geq 4$ ) pay out dividends that are, as a percentage of cashflow, $5.34 \%$ higher than firms in countries where shareholder protection is weak (revised ADR $<4$ ). When we

(DeAngelo et al., 2006). Hence, the proportion of dividend payers using Worldscope data is likely to be much lower. See Partington (2009) for a discussion of this issue. 17 The correlation between agency costs (sales-to-assets) and dividends to sales is negative as expected, given the construct of the agency cost variable. As a result, in all regressions where we include this agency cost variable, we use either dividendsto-cashflow (\%) or dividends-to-earnings (\%).

${ }^{18}$ The results are qualitatively the same when we use dividends-to-earnings (\%) and dividends-to-cashflow (\%). These results are available from the corresponding author upon request. 
Table 2

Summary statistics. This table reports summary mean and median (presented in square brackets) payout statistics by level of shareholder (country and corporate) and creditor rights. Firms are domiciled in countries with high (low) shareholder/creditor rights if their country level score for shareholder/creditor rights is equal to or greater (less than) the sample median. The median values are based on the number of countries in the sample. Dividend payout is calculated using dividends-to-cashflow. Dividends-to-cashflow is calculated as dividends per share divided by cashflow per share (expressed as a percentage). Corporate governance is calculated as sales-to-total assets. Shareholder rights are measured by one of five different measures, as indicated. Revised anti-director rights (ADR) and the anti-self-dealing index (ASD) are shareholder rights measures from Djankov et al. (2008). Investor Protection is from La Porta et al. (2006) and is calculated as the weighted average of disclosure, liability standards, and anti-director rights. Legality is an index of legal development and is measured as the weighted average of judicial efficiency, rule of law, corruption, risk of expropriation, and risk of contract repudiation (Berkowitz et al., 2003). Rule of law is from La Porta et al. (1998). Creditor rights are from Djankov et al. (2007).

\begin{tabular}{|c|c|c|c|c|c|}
\hline \multirow[t]{3}{*}{ Panel A } & \multicolumn{5}{|c|}{ Dividends-to-cashflow (\%) } \\
\hline & \multicolumn{5}{|c|}{ Shareholder rights measures } \\
\hline & Revised ADR (4.00) & Self-dealing index $(0.47)$ & Investor protection $(0.48)$ & Legality (15.55) & Rule of law (8.57) \\
\hline High shareholder rights & $13.26 \%[7.98 \%]$ & $10.59 \%[0.00 \%]$ & $9.85 \%[0.00 \%]$ & $9.97 \%[0.00 \%]$ & $8.73 \%[0.00 \%]$ \\
\hline Low shareholder rights & $7.92 \%[0.00 \%]$ & $11.89 \%[6.49 \%]$ & $12.44 \%[8.85 \%]$ & $14.06 \%[7.11 \%]$ & $15.06 \%[8.50 \%]$ \\
\hline Difference & $\begin{array}{l}5.34 \%^{* * *} \\
7.98 \%^{* * *}\end{array}$ & $\begin{array}{l}(1.30 \%)^{* * *} \\
(6.49 \%)^{* * *}\end{array}$ & $\begin{array}{l}(2.59 \%)^{* * *} \\
(8.85 \%)^{* * *}\end{array}$ & $\begin{array}{l}(4.09 \%)^{* * *} \\
(7.11 \%)^{* * *}\end{array}$ & $\begin{array}{l}(6.33 \%)^{* * *} \\
(8.50 \%)^{* * *}\end{array}$ \\
\hline
\end{tabular}

Panel B

Dividend payout measures

\begin{tabular}{|c|c|c|c|}
\hline & & & \\
\hline & Dividends-to-cashflow (\%) & Dividends-to-earnings (\%) & Dividends-to-sales (\%) \\
\hline High creditor rights & $14.08 \%[8.93 \%]$ & $24.20 \%[19.51 \%]$ & $1.43 \%[0.59 \%]$ \\
\hline Low creditor rights & $5.90 \%[0.00 \%]$ & $10.29 \%[0.00 \%]$ & $0.99 \%[0.00 \%]$ \\
\hline Difference & $8.18 \%{ }^{* * *}$ & $13.91 \%{ }^{* * *}$ & $0.44 \%{ }^{* * *}$ \\
\hline & $8.93 \%{ }^{* * *}$ & $19.51 \%^{* * *}$ & $0.59 \%^{* * *}$ \\
\hline
\end{tabular}

\begin{tabular}{llc}
\multirow{2}{*}{ Panel C } & Dividend payout measures & \\
\cline { 2 - 3 } & Dividends-to-cashflow $(\%)$ & Dividends-to-earnings $(\%)$ \\
\hline High corporate governance & $12.18 \%[6.80 \%]$ & $21.23 \%[14.77 \%]$ \\
Low corporate governance & $9.52 \%[0.00 \%]$ & $16.19 \%[0.00 \%]$ \\
Difference & $2.66 \%^{* * *}$ & $5.04 \%^{* * *}$ \\
& $6.80 \%^{* * *}$ & $14.77 \%^{* * *}$
\end{tabular}

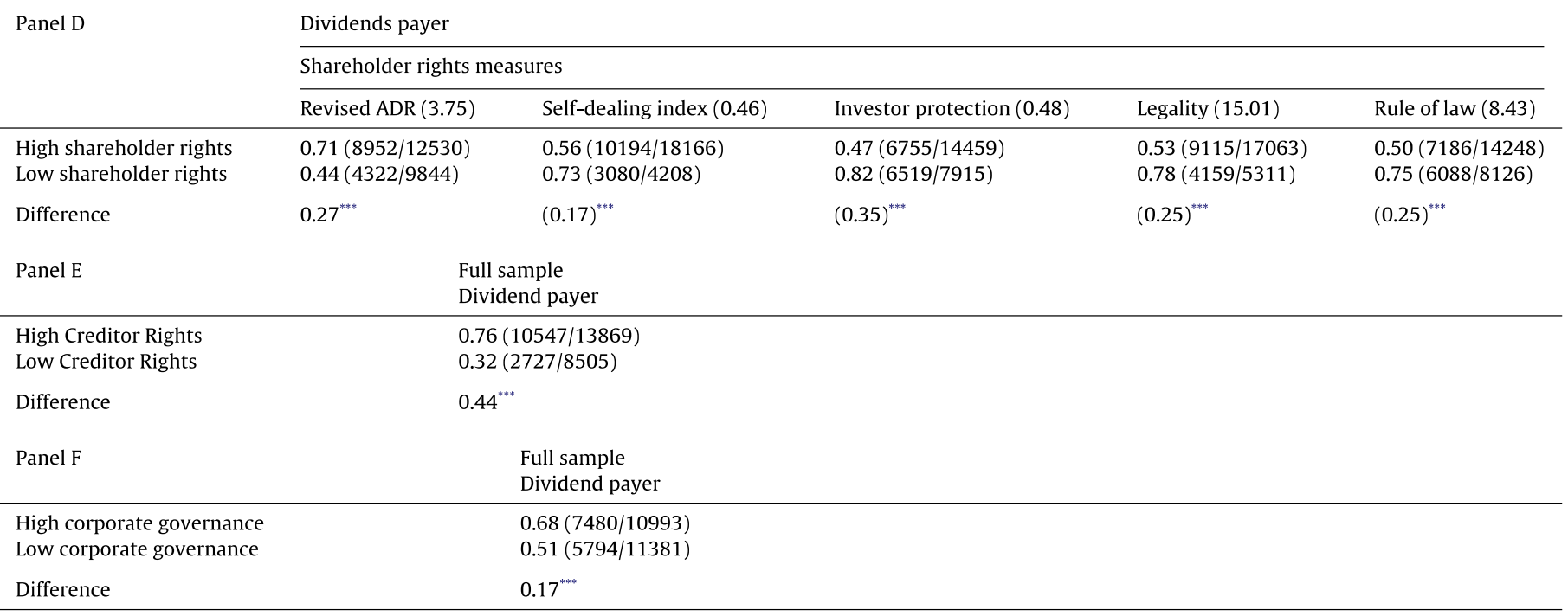

Asterisks denote significance of $t$-tests and $z$-tests of the equality of means and medians, respectively.

*** Significance at the $1 \%$ level.

consider the other measures of shareholder rights, we find support in favor of the substitution model. Firms in countries with low shareholder rights (i.e., anti-self-dealing index $<0.47$; investor protection $<0.48$; legality $<15.55$; and rule of law $<8.57$ ) pay between $1.3 \%$ and $6.33 \%$ higher, again relative to cashflow than firms in countries with high shareholder rights, depending on the measure of shareholder rights used.

We next consider how creditor rights affect the level of dividend payouts. The summary measures are presented in Panel B of Table 2. Here, we find evidence in support of the substitution model of dividends, i.e., creditors substitute low dividends for low legal rights. This is in line with Brockman and Unlu (2009). We find that high creditor rights are associated with high dividends, while low creditor rights are associated with low dividends. The difference in dividend amounts between firms in countries where creditor rights are weak and those in countries where creditor rights are strong ranges from $0.44 \%$ to $13.91 \%$.

Finally, in Panel C of Table 2, we examine how shareholder rights, measured at the firm-level, impacts dividend payout. We classify firms by level of agency costs, and deem firms as low agency costs/high corporate governance firms if their sales-toassets ratio is above the sample median. Given the construction 
of the agency cost variable, we only present summary payout measures using dividends-to-earnings (\%) and dividends-to-cashflow (\%). We find that firms with low agency costs/high corporate governance pay out higher dividends. The mean (median) firm with low agency costs/high corporate governance pays out $5.04 \% / 14.77 \%$ more of its earnings as dividends than high agency cost/low corporate governance firms. Firms with low agency costs/high corporate governance also pay a greater amount of their cashflow in the form of dividends. These findings are consistent with Mitton (2004), Bartram et al. (2008), Jiraporn et al. (2011), and Adjaoud and BenAmar (2010) who all find that better-governed firms pay higher dividends.

In the remaining columns of Table 2 , we present these summary statistics once more, but this time using dividend payer and not dividend amount as our measure of dividend payout. A firm is deemed to be a dividend payer if they pay a dividend at any point during the sample period. In line with Table 2 (Panel A), there is support for the outcome model of dividends when the revised anti-director rights index is used as the measure of shareholder rights, whereas the substitute model appears to hold when all other measures are used to proxy for country shareholder rights (Panel D). When creditor rights are considered (Panel E), we again find that dividend payouts are higher when creditor rights are strong $(0.76$ or $76 \%$ of firms pay a dividend at least once when creditor rights are strong versus 0.32 or $32 \%$ when creditor rights are weak). The results are statistically significant at the $1 \%$ level, and are in line with our earlier findings. Together (i.e., Panels B and E suggest that in line with Brockman and Unlu (2009) the likelihood of paying a dividend, and the dividend amount increase in creditor rights.

Finally, Panel F presents the same statistics, but now by level of corporate governance. Firms with better corporate governance are more likely to pay a dividend. Almost $70 \%$ of the high corporate governance sample of firms pays a dividend at least once. Only $51 \%$ of the low corporate governance sample does likewise. Together with the findings presented earlier in Table 2, this suggests that well-governed firms are more likely to pay a dividend, and when they pay a dividend, the amount of the dividend (as a \% of cashflow or earnings) is also greater than that paid by poorly governed firms. These findings are in line with Jiraporn et al. (2011). ${ }^{19}$

In summary, our findings thus far suggest that both shareholders and creditors influence dividend payouts. In turn, shareholders are able to do so, by using their country- and firm-level legal rights. Next, we take a first step towards examining whether shareholders, through their country- or firm-level legal rights, or creditors exert the greatest influence on corporate dividend payouts. To do so, we begin by presenting some summary measures. They are presented in Table 3.

A priori, we would expect that if creditors exert the greatest influence on corporate dividend payout, dividend payouts (the amount and likelihood) would be lower in countries where creditor rights are poorly protected, irrespective of the strength of shareholder rights. In turn, dividend payouts are likely to be much larger in countries where both shareholders and creditors are wellprotected under the legal system. However, here, the ability of shareholders to extract larger dividends from firms rests not on their legal rights, but on the strength of creditor rights. Thus, the ability of shareholders to force firms to pay higher dividends is dependent on the strength of creditor rights in that country. Strong shareholder rights, but absent correspondingly high creditor rights is likely to result in lower dividend payouts. In short, we expect

\footnotetext{
19 Mitton (2004) only examines the amount of the dividend payout and not the likelihood of paying a dividend. Bartram et al. (2008) examine the likelihood of paying a dividend over repurchasing shares.
}

that dividend payouts are more an outcome of creditor, as opposed to shareholder rights.

This is exactly what we find. In every case, in countries where shareholder rights are high, dividend payouts are higher when creditor rights are strong. The difference in the level of dividend payouts is approximately $7-12 \%$ and the results are statistically significant at the $1 \%$ level. This likely indicates that creditors will allow higher dividends to be paid when they are well protected under the legal regime, but mandate lower dividend payouts when their legal protection is much weaker. Hence, they substitute lower creditor rights for lower dividends. The results also show that the effect of creditor rights dominates the effect of shareholder rights, since shareholders are not able to use their legal rights to force firms to pay higher dividends when creditors are not well protected.

The same results manifest when we measure shareholder rights at the firm-level (Panel B). Again, dividend payouts are larger when both shareholders and creditors enjoy considerable protection at the firm, and country level, respectively. When shareholder rights are strong (at the firm level), but creditor rights not so, dividend payouts tend to be much smaller, than in the case where creditor and shareholder rights are strong. The difference in dividend payouts in both instances is economically large and statistically significant. For instance, when corporate governance and creditor rights are strong, the average firm pays out $8.33 \%$ (14.70\%) more of its cashflow (earnings) as dividends, than the average firm with similar governance, but who is domiciled in a country where creditor rights are low. Together, the findings from Panels A and B suggest that the ability of shareholders to use their legal rights, be they country- or firm-level, to force firms to pay higher dividends is very much contingent on the strength of creditor rights in that country. Creditors demand, and shareholders must accept, lower dividends, when creditor legal protection is weak. When both shareholder and creditor rights are strong, dividend payouts are much larger. As such, creditors consent to much larger dividends when both they and shareholders are well-protected. ${ }^{20}$ Next, we examine the extent to which creditors influence the propensity to pay dividends in the first instance.

In Panel C of Table 3 we report the propensity to pay statistics by the level of creditor rights and creditor and shareholder rights. Shareholder rights are measured at the country- and firmlevel. Again, and in line with Brockman and Unlu (2009), and with our earlier findings, we find support in favor of the substitution model. Once again, we find that, in countries where shareholder rights are strong, the likelihood of a firm paying a dividend is much higher when creditor rights are also strong. The difference is between 0.44 and 0.55 , depending on which measure of shareholder rights is used. This supports our earlier findings that firms are more likely to pay dividends if creditors know they are well protected. Finally, we examine how the interaction of shareholder rights (at the firm level) and creditor rights impact on the propensity to pay a dividend. Here again, we find that the strength of creditor rights impacts on the ability of shareholders to use their legal rights to force firms to pay higher dividends. When shareholders and creditors are well protected, the propensity to pay dividends is much higher than in instances where only shareholders are well protected. The difference is large ( 0.85 versus 0.42$)$, and is statistically significant.

\footnotetext{
20 In turn, we also show in unreported analysis, that dividend payouts are lower when shareholder rights are weak and creditor rights strong, than in the case where both are well-protected. In this instance, creditors do not demand higher dividends despite the agency costs of equity associated with poor shareholder rights. The results are available from the corresponding author upon request.
} 
Table 3

Summary statistics. This table reports summary mean and median (presented in square brackets) payout statistics and propensity to pay statistics by level of shareholder rights and the interaction of shareholder and creditor rights. Firms are domiciled in countries with high (low) shareholder/creditor rights if their country level score for shareholder/creditor rights is equal to or greater (less than) the sample median. The median values are based on the number of countries in the sample. Dividend payout is calculated using dividends-to-cashflow (\%). Dividends-to-cashflow (\%) is calculated as dividends per share divided by cashflow per share (expressed as a percentage). A firm is deemed a dividend payer if they pay a dividend at any point during the sample period. Shareholder rights are measured by either one of five different measures, as indicated. Corporate governance is calculated as sales-to-total assets. Revised anti-director rights (ADR) and the anti-self-dealing index (ASD) are shareholder rights measures from Djankov et al. (2008). Investor protection is from La Porta et al. (2006) and is calculated as the weighted average of disclosure, liability standards, and anti-director rights. Legality is an index of legal development and is measured as the weighted average of judicial efficiency, rule of law, corruption, risk of expropriation, and risk of contract repudiation (Berkowitz et al., 2003). Rule of law is from La Porta et al. (1998). Creditor rights are from Djankov et al. (2007).

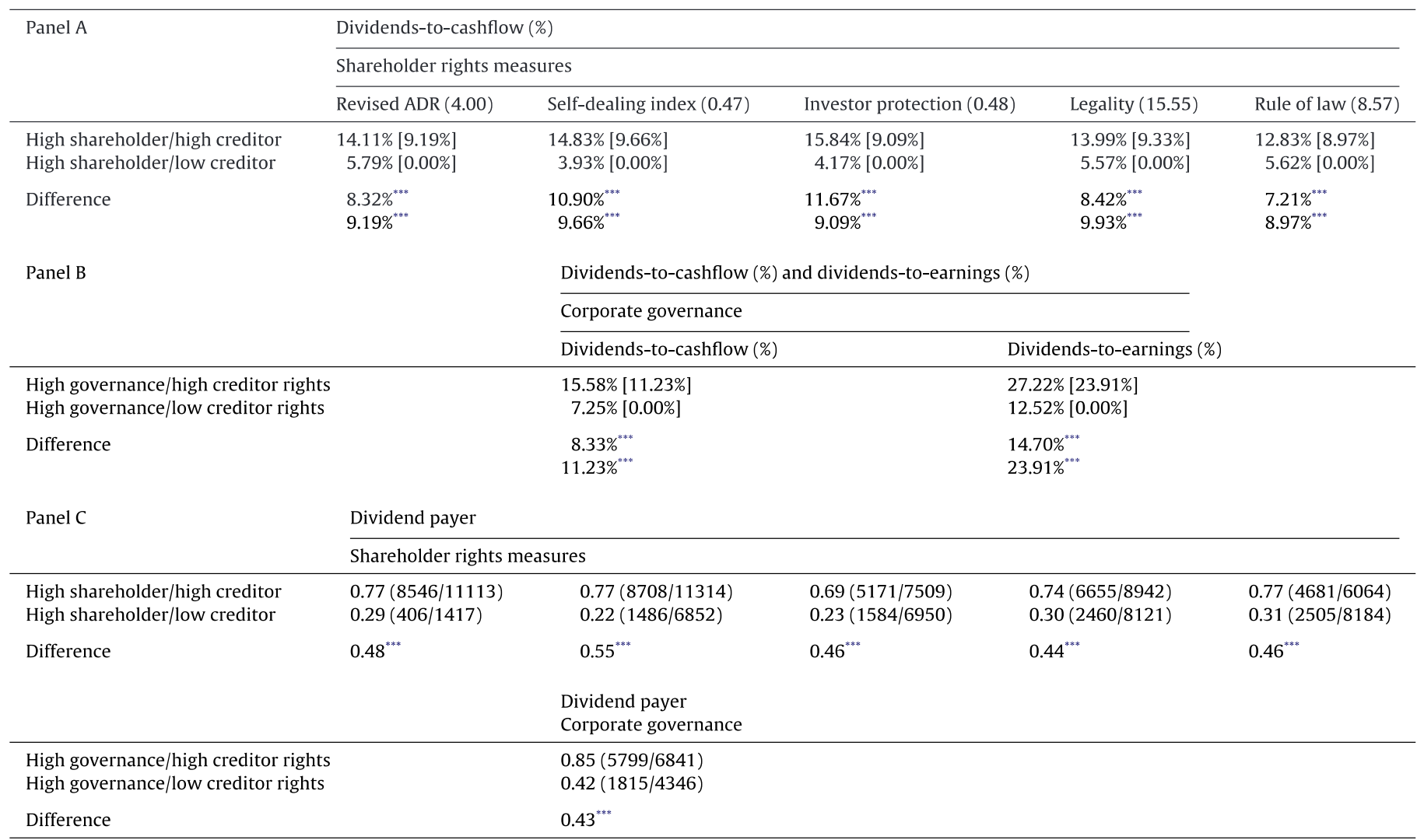

Asterisks denote significance of $t$-tests and $z$-tests of the equality of means and medians, respectively.

${ }^{* * *}$ Significance at the $1 \%$ level.

Our summary measures suggest that creditors exert the greatest influence over corporate dividend policy. The likelihood and the dividend amount are greater when both shareholders and creditors enjoy substantial legal rights. When creditors are not so well endowed with legal rights, dividend payouts tend to be much lower. Hence, creditors appear to substitute poor legal rights for lower dividends. Then, if anything, the outcome model of dividends, that is, the ability of shareholders to extract larger dividends from firms relies crucially on both the strength of shareholder and creditor rights, and not shareholder rights alone, as originally suggested in the literature. In the next section, we examine whether these relations still hold, when we present some conditional estimates from a series of Tobit and logit regressions.

\section{Regression estimates}

In Table 4, we consider the relationship between country legal rights (shareholder and creditor), shareholder rights at the firm-level (corporate governance) and the likelihood of paying a dividend. We present our results from pooled fixed effect logit regressions. The dependent variable is dividend payer, which is equal to one if the firm pays a dividend, and zero otherwise. In all regressions, we include firm-level controls (firm size, firm profitability, and firm growth opportunities), year and industry fixed effects (both unreported), and report the marginal effects, evaluated at the mean of each independent variable. Finally, we report $z$-statistics, which are robust to firm-level clustering (see Petersen, 2009).

We find all three of our primary explanatory variables to be statistically significant at the $1 \%$ level. When the revised ADR index is used as a measure of shareholder rights, the coefficient estimate is positive and significant. This result lends support to the outcome model of dividends and is in line with many others, including La Porta et al. (2000), Mitton (2004), and Brockman and Unlu (2009). Shareholders can extract higher dividends from firms when they enjoy sizable legal rights. However, when any of the other four measures are used to proxy shareholder rights, we find a negative relationship between shareholder rights and the likelihood of paying a dividend. In columns $2-5$, we find results that support the substitution model of dividends. The negative relationship between shareholder rights and dividend payer implies that the likelihood of paying a dividend is higher in countries with weak shareholder rights because dividends substitute for poorer shareholder rights. In turn, this suggests that the firms most likely to pay dividends are firms with the greatest need for external finance, as 
Table 4

Dividend payer, shareholder and creditor rights. This table reports marginal effects from pooled fixed-effect logit regressions with $z$-stats adjusted for clustering at the firm level presented underneath in parenthesis. The marginal effects are evaluated at the sample mean of each variable. Panel A reports the marginal effects for the full sample of firms (full sample). In Panel B we exclude all firms from Japan, the U.K., and the U.S. (reduced sample). The sample period is 1991-2007. In each regression shareholder rights is measured using a different proxy, as indicated. The dependent variable is dividend paper. Dividend payer equals one if the firm pays a dividend, and is zero otherwise. All country and firm-level variables are defined in the main text. All firm-level variables are winsorized at the 1st and 99th percentiles. A full set of year and industry fixed effects are included but not reported.

\begin{tabular}{|c|c|c|c|c|c|}
\hline \multirow[t]{3}{*}{ Panel A } & \multicolumn{5}{|c|}{ Dividend payer and full sample } \\
\hline & \multicolumn{5}{|c|}{ Shareholder rights measured as } \\
\hline & $\begin{array}{l}\text { Revised ADR } \\
\text { (1) }\end{array}$ & $\begin{array}{l}\text { Self-dealing index } \\
\text { (2) }\end{array}$ & $\begin{array}{l}\text { Investor protection } \\
\text { (3) }\end{array}$ & $\begin{array}{l}\text { Legality } \\
(4)\end{array}$ & $\begin{array}{l}\text { Rule of law } \\
\text { (5) }\end{array}$ \\
\hline Shareholder rights & $0.190^{* * *}(34.99)$ & $-0.497^{* * *}(22.89)$ & $-0.533^{* * *}(38.68)$ & $-0.014^{* * *}(11.67)$ & $-0.033^{* * *}(16.81)$ \\
\hline Creditor rights & $0.040^{* * *}(9.41)$ & $0.178^{* * *}(41.52)$ & $0.103^{* * *}(34.11)$ & $0.129^{* * *}(38.31)$ & $0.118^{* * *}(35.02)$ \\
\hline Corporate governance & $0.047^{* * *}(10.08)$ & $0.031^{* * *}(6.72)$ & $0.038^{* * *}(8.54)$ & $0.045^{* * *}(9.30)$ & $0.047^{* * *}(9.88)$ \\
\hline Firm size & $0.107^{* * *}(52.24)$ & $0.099^{* * *}(48.51)$ & $0.099^{* * *}(49.82)$ & $0.107^{* * *}(51.21)$ & $0.108^{* * *}(51.55)$ \\
\hline Firm growth & $-0.120^{* * *}(17.68)$ & $-0.119^{* * *}(18.92)$ & $-0.092^{* * *}(14.68)$ & $-0.133^{* * *}(20.96)$ & $-0.131^{* * *}(20.55)$ \\
\hline Firm profitability & $2.450^{* * *}(73.18)$ & $2.447^{* * *}(73.07)$ & $2.530^{* * *}(78.14)$ & $2.341^{* * *}(68.89)$ & $2.332^{* * *}(69.26)$ \\
\hline Year dummies & Included & Included & Included & Included & Included \\
\hline Industry dummies & Included & Included & Included & Included & Included \\
\hline \#Observations & 188,738 & 188,738 & 188,738 & 188,738 & 188,738 \\
\hline \multirow[t]{3}{*}{ Panel B } & \multicolumn{5}{|c|}{ Dividend payer and reduced sample } \\
\hline & \multicolumn{5}{|c|}{ Shareholder rights measured as } \\
\hline & $\begin{array}{l}\text { Revised ADR } \\
\text { (1) }\end{array}$ & $\begin{array}{l}\text { Anti-self-dealing index } \\
(2)\end{array}$ & $\begin{array}{l}\text { Investor protection } \\
\text { (3) }\end{array}$ & $\begin{array}{l}\text { Legality } \\
(4)\end{array}$ & $\begin{array}{l}\text { Rule of law } \\
\text { (5) }\end{array}$ \\
\hline Shareholder rights & $0.043^{* * *}(7.24)$ & $0.138^{* * *}(6.37)$ & $-0.016(0.85)$ & $-0.003^{*}(1.98)$ & $-0.007^{* * *}(3.46)$ \\
\hline Creditor rights & $0.030^{* * *}(6.50)$ & $0.030^{* * *}(6.23)$ & $0.045^{* * *}(10.85)$ & $0.045^{* * *}(10.80)$ & $0.043^{* * *}(10.36)$ \\
\hline Corporate governance & $0.080^{* * *}(12.18)$ & $0.083^{* * *}(12.35)$ & $0.074^{* * *}(11.35)$ & $0.077^{* * *}(11.70)$ & $0.078^{* * *}(11.86)$ \\
\hline Year dummies & Included & Included & Included & Included & Included \\
\hline Industry dummies & Included & Included & Included & Included & Included \\
\hline Firm controls & Included & Included & Included & Included & Included \\
\hline \#Observations & 92,406 & 92,406 & 92,406 & 92,406 & 92,406 \\
\hline
\end{tabular}

* Significance at the $10 \%$ level.

Significance at the $1 \%$ level.

the substitution model suggests. Since shareholder legal protection is weak, firms bond to greater protection of their shareholders by paying dividends, which in turn substitute for poor shareholder protection. In this regard, firms use dividend payouts as a bonding mechanism for these firms. ${ }^{21}$ By their very nature, better-governed firms do not require dividends to fulfill such a bonding role. Finally, the firm-level controls are statistically significant and of the correct sign. Consistent with the life-cycle model of dividends, large, profitable firms, with low growth opportunities are more likely to pay dividends. The marginal effects suggest that profitability, growth, and then size in that order exert the greatest influence on the decision of the firm to pay a dividend.

Next, we examine the effect of creditor rights on dividend payout. In line with the summary measures presented in Table 2, creditor rights have a positive and significant effect on whether a firm pays a dividend. Using the full sample, the marginal effects range from 0.040 and 0.178 , depending on which measure of shareholder rights is used. The results are in line with Brockman and Unlu (2009). Finally, we show that corporate governance matters for whether a firm pays a dividend. The coefficient estimates are positive and statistically significant. These results are in line with Mitton (2004), Bartram et al. (2008), Adjaoud and Ben-Amar (2010), and Jiraporn et al. (2011) who all show that dividend payouts increase in the strength of corporate governance. ${ }^{22}$ Furthermore,

\footnotetext{
21 And improvements in corporate governance lessen the bonding role of dividends (Adjaoud \& Ben-Amar, 2010; O'Connor, 2006).

22 Mitton (2004) uses Credit Lyonnais Securities Asia (CLSA, 2001) corporate governance data; Bartram et al. (2008) use a series of agency cost measures, Jiraporn
}

and like both Mitton (2004) and Bartram et al. (2008), shareholder rights measured at the country- and firm-level influence corporate dividend payouts. When included simultaneously, both have explanatory power. However, country legal rights appear to dominate corporate legal rights. ${ }^{23}$ Furthermore, we also find that the creditor rights effect dominates the firm-level corporate governance effect. We also find that given the inclusion of creditor rights, shareholder rights at the country- and firm-level still influence corporate dividend payout. Finally, and unlike Brockman and Unlu (2009), we do not find that dividend payouts are more sensitive to creditor rights than to shareholder rights. In fact, we find the opposite. Shao et al. (2009) find likewise in their paper.

One issue that may arise is that a large proportion of the firms included in our final sample are from the U.S., the U.K. and Japan. Concerned that firms in these countries may be driving our results, we exclude these countries and re-run our regression analysis on a reduced sample. The results are presented in Panel B of Table 4. Again, we find all of our explanatory variables to be statistically significant at the $1 \%$ level. Now when either the revised ADR or the anti-self-dealing index is used as a measure for shareholder rights, there is evidence in favor of the outcome model of dividends. When any of the other measures are used, there is support for the substitution model.

et al. (2011) uses governance data from the Institutional Shareholder Services (ISS) and Adjaoud and Ben-Amar (2010) use the Globe \& Mail corporate governance index for Canadian firms.

${ }^{23}$ Mitton (2004) finds likewise. Country-level shareholder rights dominate firmlevel shareholder rights in determining corporate dividend payout. 
Table 5

Dividend payout, shareholder and creditor rights. This table reports marginal effects from pooled fixed-effect tobit regressions with $z$-stats adjusted for clustering at the firm level presented underneath in parenthesis. The marginal effects are evaluated at the sample mean of each variable, and correspond to the marginal effect of each independent variable on the observed dependent variable. Panel A reports the marginal effects for the full sample of firms (full sample). In Panel B we exclude all firms from Japan, the U.K., and the U.S. (reduced sample). The sample period is 1991-2007. In each regression shareholder (\%) rights is measured using a different proxy, as indicated. The dependent variable is dividends-to-cashflow. Dividends-to-cashflow (\%) is calculated as dividends per share divided by cashflow per share. All country and firm-level variables are defined in the main text. All firm-level variables are winsorized at the 1 st and 99th percentiles. A full set of year and industry fixed effects are included but not reported.

\begin{tabular}{|c|c|c|c|c|c|}
\hline \multirow[t]{3}{*}{ Panel A } & \multicolumn{5}{|c|}{ Dividends-to-cashflow (\%) and full sample } \\
\hline & \multicolumn{5}{|c|}{ Shareholder rights measured as } \\
\hline & $\begin{array}{l}\text { Revised ADR } \\
\text { (1) }\end{array}$ & $\begin{array}{l}\text { Self-dealing index } \\
\text { (2) }\end{array}$ & $\begin{array}{l}\text { Investor protection } \\
\text { (3) }\end{array}$ & $\begin{array}{l}\text { Legality } \\
(4)\end{array}$ & $\begin{array}{l}\text { Rule of law } \\
\text { (5) }\end{array}$ \\
\hline Shareholder rights & $0.020^{* * *}(22.86)$ & $-0.043^{* * *}(13.65)$ & $-0.064^{* * *}(32.21)$ & $-0.003^{* * *}(12.18)$ & $-0.004^{* * *}(12.32)$ \\
\hline Creditor rights & $0.014^{* * *}(20.49)$ & $0.028^{* * *}(44.59)$ & $0.021^{* * *}(37.31)$ & $0.024^{* * *}(42.22)$ & $0.023^{* * *}(39.29)$ \\
\hline Corporate governance & $0.003^{* * *}(3.45)$ & $0.001(1.37)$ & $0.002^{* *}(2.19)$ & $0.003^{* * *}(3.79)$ & $0.003^{* * *}(3.62)$ \\
\hline Firm size & $0.012^{* * *}(46.54)$ & $0.012^{* * * *}(42.71)$ & $0.011^{* * *}(41.33)$ & $0.013^{* * *}(46.88)$ & $0.013^{* * *}(46.78)$ \\
\hline Firm growth & $-0.027^{* * *}(22.89)$ & $-0.028^{* * *}(23.61)$ & $-0.024^{* * *}(20.70)$ & $-0.030^{* * *}(24.65)$ & $-0.029^{* * *}(24.49)$ \\
\hline Firm profitability & $0.454^{* * *}(90.14)$ & $0.459^{* * *}(91.33)$ & $0.453^{* * *}(93.86)$ & $0.449^{* * *}(87.71)$ & $0.449^{* * *}(87.46)$ \\
\hline Year dummies & Included & Included & Included & Included & Included \\
\hline Industry dummies & Included & Included & Included & Included & Included \\
\hline \#Observations & 188,738 & 188,738 & 188,738 & 188,738 & 188,738 \\
\hline \multirow[t]{3}{*}{ Panel B } & \multicolumn{5}{|c|}{ Dividends-to-cashflow (\%) and reduced sample } \\
\hline & \multicolumn{5}{|c|}{ Shareholder rights measured as } \\
\hline & $\begin{array}{l}\text { Revised ADR } \\
\text { (1) }\end{array}$ & $\begin{array}{l}\text { Anti-self-dealing index } \\
(2)\end{array}$ & $\begin{array}{l}\text { Investor protection } \\
(3)\end{array}$ & $\begin{array}{l}\text { Legality } \\
(4)\end{array}$ & $\begin{array}{l}\text { Rule of law } \\
\text { (5) }\end{array}$ \\
\hline Shareholder rights & $0.001(0.76)$ & $0.053^{* * *}(12.09)$ & $0.013^{* * *}(3.57)$ & $0.001^{* *}(2.14)$ & $0.002^{* * *}(4.08)$ \\
\hline Creditor rights & $0.012^{* * * *}(13.13)$ & $0.010^{* * *}(7.40)$ & $0.012^{* * *}(14.36)$ & $0.012^{* * *}(14.53)$ & $0.012^{* * *}(14.08)$ \\
\hline Corporate governance & $0.010^{* * *}(6.89)$ & $0.012^{* * *}(8.80)$ & $0.010^{* * *}(7.22)$ & $0.010^{* * *}(6.52)$ & $0.010^{* * *}(6.36)$ \\
\hline Year dummies & Included & Included & Included & Included & Included \\
\hline Industry dummies & Included & Included & Included & Included & Included \\
\hline Firm controls & Included & Included & Included & Included & Included \\
\hline \#Observations & 92,406 & 92,406 & 92,406 & 92,406 & 92,406 \\
\hline
\end{tabular}

${ }^{* *}$ Significance at the $5 \%$ level.

*** Significance at the $1 \%$ level.

When considering the reduced sample, the coefficient estimates on the creditor rights variable, although still positive and significant, are lower. The difference may be because of the large number of U.S. firms included in the full sample. Finally, we examine the effect of corporate governance on dividend payout using the reduced sample. As before, the coefficient estimates on the corporate governance variable is positive and significant, suggesting that the likelihood of a dividend being paid is higher in countries where shareholder rights measured at the firm-level are strong. In the case of the reduced sample, the coefficient estimates are much higher than in the full sample.

Next, we consider the relationship between corporate governance, legal rights and the dividend amount using a series of pooled fixed effects Tobit regressions. The dependent variable is dividends-to-cashflow (\%). The results for the full sample of countries are presented in Table 5, Panel A. In all regressions, we include firm-level controls (firm size, firm profitability, and firm growth opportunities), year and industry fixed effects (both unreported), and report marginal effects, again evaluated at the mean of each independent variable. Finally, and again as before, we report $z$ statistics, which are robust to firm-level clustering. Once again, we find shareholder rights, creditor rights, and corporate governance to be statistically significant. There is support for the outcome model of dividends when the revised anti-director rights index is used to measure the strength of shareholder rights at the country level. Again, we find support in favor of the substitution model when any other measure of country-level shareholder rights is used. Creditor rights have a positive and significant effect on the level of dividends in all cases. The amount of dividends paid also increases in the level of corporate governance. The country-level shareholder rights effect again dominates the firm-level corporate governance measure. Also, and consistent with earlier, we find that the amount of dividends paid is much more sensitive to shareholder rights (measured at the country-level) than creditor rights. These results contradict Brockman and Unlu (2009), but are in line with Shao et al. (2009). ${ }^{24}$ Finally, in all specifications, the firmlevel control variables are statistically significant, and based on the predictions of the life-cycle model of dividends, correctly signed. Large, profitable firms, with low growth opportunities pay higher dividends than small firms with high growth, but little or no profits.

In Panel B of Table 5, we present results for the reduced sample of countries. Now, irrespective of the measure we use for shareholder rights, there is evidence in support of the outcome model of dividends. The positive coefficient estimates imply that dividend payouts are much higher in countries (\%) where shareholder rights are strong. The marginal effects on the creditor rights variable are positive, although are only about half of the magnitude of the coefficient estimates for the full sample (ranging between 0.014 and 0.028 across the full sample, and between 0.010 and 0.012 across the reduced sample). As before, we find the marginal effects on the corporate governance variable to be positive and statistically significant. The marginal effects estimates range from 0.010 and 0.012 for the reduced sample, compared to between 0.001 and 0.003 for the full sample.

We now consider the effect of shareholder rights and corporate governance on dividends for differing levels of creditor rights. Here we examine whether the likelihood of paying a dividend is greatest

\footnotetext{
${ }^{24}$ In their logit regressions, the coefficient estimate on the shareholder rights measure $(0.365)$ is larger than the coefficient estimate on the creditor rights variable (0.138).
} 
when shareholder and creditor rights are both strong. The findings are presented in Table 6 . This appears to be the case. We find a positive relationship between shareholder rights and the likelihood of paying dividends in countries where creditor rights are strong. Surprisingly, we also find that, in countries where creditor rights are weak, shareholder rights measured at the country-level and the likelihood of paying dividends are negatively related. While we cannot offer an explanation for this finding, our results do suggest that the outcome model is more relevant under strong creditor protection. Finally, we find that corporate governance matters more when creditor rights are strong. Interestingly, when shareholder rights are measured at the firm-level, we find support in favor of the outcome model given strong and weak creditor rights. However, the likelihood of a firm not paying a dividend is much greater when creditors are not well-protected. This result contrasts notably with the findings when we measure shareholder rights at the countrylevel.

We repeat the analysis excluding firms domiciled in the U.S., the U.K., and Japan and present the results in Panel B. Again, we find a positive relationship between shareholder rights and the likelihood of paying dividends in countries where creditor rights are strong. The relationship is much weaker when creditor rights are weak.

Finally, we repeat our analysis with dividends-to-cashflow (\%) as the dependent variable. We report the coefficient estimates from pooled fixed-effect Tobit regressions in Table 7. In all regressions, we re-estimate the regressions presented in Table 5, but now for firms domiciled in countries where creditor rights is either above or below the median country creditor rights level. The creditor rights variable is excluded in all regressions. The summary measures presented in Table 3 suggest that dividend payouts are larger where shareholder and creditor rights are strong. In Table 6 , we examine whether this relationship holds when we control for firm-level factors, industry and time fixed effects. The results suggest that they do. Specifically, when creditor rights are strong, dividend payout increases as shareholder rights increase. The results are particularly striking when the anti-self-dealing index or the level of investor protection are used to measure shareholder rights. When creditor rights are weak, we find a negative relationship between shareholder rights and dividend payouts. The size of the marginal effects is dependent on which measure of shareholder rights is used. These results support the findings of Shao et al. (2009) who find that the outcome model is more effective in countries where creditor rights are strong. Our paper differs to theirs since we also examine whether creditor rights impacts on the ability of shareholders to use their legal rights at the corporate level to influence corporate dividend policy. This is where we turn to next.

Creditors also appear to exert sizable influence on the ability of shareholders to use their legal rights at the firm-level to extract dividends from firms. With one exception, we find that the marginal effects estimates on the corporate governance variable are larger when creditors are well-protected under the legal regime. Where they are not, the marginal effects are much lower, but unlike the case when shareholder rights are measured at the country-level, the coefficient estimates remain positive, and also statistically significant. Under weak creditor rights, the outcome model remains relevant, albeit much less so, when shareholder rights are measured at the firm-level. These findings also hold across the reduced sample.

In summary, we find that creditors exert sizable influence over corporate dividend payouts. The influence is much greater than shareholder rights, which in turn suggests that ability of shareholders to extract large dividend payouts from firms is very much contingent on both shareholder and creditor rights. Where both are strong, the likelihood of paying a dividend and the dividend amount

Table 6

Dividend payer regressions by level of creditor rights. This table reports marginal effects from pooled fixed-effect logit regressions with $z$-stats adjusted for clustering at the firm level presented underneath in parenthesis. The marginal effects are evaluated at the sample mean of each variable. The sample period is 1991-2007. Panel A reports the marginal effects for the full sample of firms (full sample). In Panel B we exclude all firms from Japan, the U.K., and the U.S. (reduced sample). In each regression shareholder rights is measured using a different proxy, as indicated. The dependent variable is dividend paper. Dividend payer equals one if the firm pays a dividend, and is zero otherwise. Separate regressions are reported for firms in countries with above- and below-median creditor rights. All country and firm-level variables are defined in the main text. All firm-level variables are included, but not reported, and are winsorized at the 1 st and 99th percentiles. A full set of year and industry fixed effects are included but not reported.

\begin{tabular}{|c|c|c|c|c|c|}
\hline \multirow[t]{2}{*}{ Panel A } & \multicolumn{5}{|c|}{ Dividend payer and full sample } \\
\hline & Revised ADR & Self-dealing index & Investor protection & Legality & Rule of law \\
\hline \multicolumn{6}{|l|}{ Above median creditor rights } \\
\hline Shareholder rights & $0.384^{* * *}(16.76)$ & $0.066^{* * *}(3.48)$ & $0.103^{* * *}(5.38)$ & $0.023^{* * *}(14.52)$ & $0.027^{* * *}(10.99)$ \\
\hline Corporate governance & $0.370^{* * *}(13.80)$ & $0.089^{* * *}(13.65)$ & $0.091^{* * *}(13.89)$ & $0.072^{* * *}(11.22)$ & $0.077^{* * *}(11.92)$ \\
\hline \#Observations & 114,255 & 114,255 & 114,255 & 114,255 & 114,255 \\
\hline Controls/industry and year dummies & Included & Included & Included & Included & Included \\
\hline \multicolumn{6}{|l|}{ Below median creditor rights } \\
\hline Shareholder rights & $0.103^{* * *}(16.25)$ & $-0.440^{* * *}(22.59)$ & $-0.240^{* * *}(23.39)$ & $-0.015^{* * *}(12.21)$ & $-0.027^{* * *}(13.51)$ \\
\hline Corporate governance & $0.011^{* * *}(3.37)$ & $0.012^{* * *}(4.35)$ & $0.012^{* * *}(4.64)$ & $0.010^{* * *}(3.10)$ & $0.011^{* * *}(3.27)$ \\
\hline \#Observations & 74,483 & 74,483 & 74,483 & 74,483 & 74,483 \\
\hline Controls/industry and year dummies & Included & Included & Included & Included & Included \\
\hline \multirow[t]{2}{*}{ Panel B } & \multicolumn{5}{|c|}{ Dividend payer and reduced sample } \\
\hline & Revised ADR & Self-dealing index & Investor protection & Legality & Rule of law \\
\hline \multicolumn{6}{|l|}{ Above median creditor rights } \\
\hline Shareholder rights & $0.060^{* * *}(10.25)$ & $0.244^{* * *}(11.48)$ & $0.218^{* * *}(10.87)$ & $0.003(1.54)$ & $0.001(0.03)$ \\
\hline Corporate governance & $0.069^{* * *}(9.20)$ & $0.076^{* * *}(9.90)$ & $0.075^{* * *}(9.78)$ & $0.058^{* * *}(7.87)$ & $0.059^{* * *}(8.05)$ \\
\hline \#Observations & 66,987 & 66,987 & 66,987 & 66,987 & 66,987 \\
\hline Controls/industry and year dummies & Included & Included & Included & Included & Included \\
\hline \multicolumn{6}{|l|}{ Below median creditor rights } \\
\hline Shareholder rights & $-0.076^{* * *}(4.80)$ & $-0.550^{* * *}(9.57)$ & $-0.406^{* * *}(12.13)$ & $0.003(1.20)$ & $-0.002(0.43)$ \\
\hline Corporate governance & $0.018^{* * *}(9.32)$ & $0.019^{* * *}(8.92)$ & $0.025^{* * *}(8.80)$ & $0.017^{* * *}(9.02)$ & $0.019^{* * *}(9.19)$ \\
\hline \#Observations & 25,419 & 25,419 & 25,419 & 25,419 & 25,419 \\
\hline Controls/industry and year dummies & Included & Included & Included & Included & Included \\
\hline
\end{tabular}

*** Significance at the $10 \%$ level. 
Table 7

Dividend payout regressions by level of creditor rights. This table reports marginal effects from pooled fixed-effect tobit regressions with $z$-stats adjusted for clustering at the firm level presented underneath in parenthesis. The marginal effects are evaluated at the sample mean of each variable, and correspond to the marginal effect of each independent variable on the observed dependent variable. Panel A reports the marginal effects for the full sample of firms (full sample). In Panel B we exclude all firms from Japan, the U.K., and the U.S. (reduced sample). The sample period is 1991-2007. In each regression shareholder rights is measured using a different proxy, as indicated. The dependent variable is dividends-to-cashflow. Dividends-to-cashflow (\%) is calculated as dividends per share divided by cashflow per share. Separate regressions are reported for firms in countries with above- and below-median creditor rights. All country and firm-level variables are defined in the main text. All firm-level variables are included, but not reported, and are winsorized at the 1 st and 99th percentiles. A full set of firm controls, year and industry fixed effects are included but not reported.

\begin{tabular}{|c|c|c|c|c|c|}
\hline \multirow[t]{2}{*}{ Panel A } & \multicolumn{5}{|c|}{ Dividends-to-cashflow (\%) and full sample } \\
\hline & Revised ADR & Self-dealing index & Investor protection & Legality & Rule of law \\
\hline \multicolumn{6}{|l|}{ Above median creditor rights } \\
\hline Shareholder rights & $0.010^{* * *}(6.08)$ & $0.072^{* * *}(16.72)$ & $0.071^{* * *}(16.31)$ & $0.004^{* * *}(10.57)$ & $0.006^{* * *}(12.50)$ \\
\hline Corporate governance & $0.010^{* * *}(6.18)$ & $0.010^{* * *}(7.88)$ & $0.010^{* * *}(7.70)$ & $0.010^{* * *}(4.49)$ & $0.010^{* * *}(4.53)$ \\
\hline \#Observations & 114,255 & 114,255 & 114,255 & 114,255 & 114,255 \\
\hline Controls/industry and year dummies & Included & Included & Included & Included & Included \\
\hline \multicolumn{6}{|l|}{ Below median creditor rights } \\
\hline Shareholder rights & $0.016^{* * *}(16.65)$ & $-0.064^{* * *}(22.92)$ & $-0.035^{* * *}(23.31)$ & $-0.003^{* * *}(12.58)$ & $-0.005^{* * *}(14.69)$ \\
\hline Corporate governance & $0.001(1.15)$ & $0.001^{* *}(2.46)$ & $0.001^{* * *}(2.72)$ & $0.001(1.25)$ & $0.001(1.40)$ \\
\hline \#Observations & 74,483 & 74,483 & 74,483 & 74,483 & 74,483 \\
\hline Controls/industry and year dummies & Included & Included & Included & Included & Included \\
\hline \multirow[t]{2}{*}{ Panel B } & \multicolumn{5}{|c|}{ Dividends-to-cashflow (\%) and reduced sample } \\
\hline & Revised ADR & Self-dealing index & Investor protection & Legality & Rule of law \\
\hline \multicolumn{6}{|l|}{ Above median creditor rights } \\
\hline Shareholder rights & $0.010^{* * *}(4.30)$ & $0.086^{* * *}(17.01)$ & $0.072^{* * *}(15.38)$ & $0.003^{* * *}(8.04)$ & $0.006^{* * *}(10.36)$ \\
\hline Corporate governance & $0.010^{* * *}(4.24)$ & $0.011^{* * *}(6.78)$ & $0.010^{* * *}(6.07)$ & $0.005^{* * *}(2.87)$ & $0.005^{* * *}(2.76)$ \\
\hline \#Observations & 66,987 & 66,987 & 66,987 & 66,987 & 66,987 \\
\hline Controls/industry and year dummies & Included & Included & Included & Included & Included \\
\hline \multicolumn{6}{|l|}{ Below median creditor rights } \\
\hline Shareholder rights & $-0.013^{* * *}(4.78)$ & $-0.091^{* * *}(10.49)$ & $-0.070^{* * *}(14.31)$ & $-0.001(0.49)$ & $-0.002^{* *}(2.09)$ \\
\hline Corporate governance & $0.010^{* * *}(8.33)$ & $0.007^{* * *}(8.09)$ & $0.006^{* * *}(7.83)$ & $0.004^{* * *}(8.04)$ & $0.004^{* * *}(8.24)$ \\
\hline \#Observations & 25,419 & 25,419 & 25,419 & 25,419 & 25,419 \\
\hline Controls/industry and year dummies & Included & Included & Included & Included & Included \\
\hline
\end{tabular}

*** Significance at the $5 \%$ level.

**** Significance at the $1 \%$ level.

tend to be high. Where creditor rights are weak, the impact of shareholder rights on dividend payout is weakened. In such instances, the likelihood of, and the amount of the dividend are much lower. ${ }^{25}$

\section{Robustness}

One area of potential concern with our analysis may be our use of the sales-to-assets ratio as a measure of corporate governance. In order to ensure that the sales-to-assets ratio is capturing a genuine corporate governance effect, we carry out some additional analysis. To do so, we replicate and then extend the work of Mitton (2004). We begin by gathering Credit Lyonnais Securities Asia (CLSA, 2001) corporate governance data for a selection of emerging market country firms. Using this sample of firms, we source from Worldscope, the same corporate dividend payout and control variables for each firm that we used in our earlier analysis. Our final sample is made up of 304 firms from 21 emerging market countries. We are unable to fully identify all of the 365 firms that Mitton (2004) uses. To maximize sample size, and unlike Mitton (2004), and others, we include firms from countries which require mandatory dividend payouts, e.g., Brazil. Nevertheless, we find that our findings remain unchanged when we exclude these firms. Finally, and also consistent with Mitton (2004), we employ the full/composite CLSA governance scores for each firm which is a weighted average of management discipline, transparency, independence,

\footnotetext{
25 In unreported tests, we show that our main findings are robust to the inclusion of a lagged dependent variable in our logit and tobit regressions. These tests are available from the corresponding author upon request. We thank an anonymous referee for suggesting that we explore this issue.
}

accountability, responsibility, fairness, and social responsibility. The first six components have a $15 \%$ weighted in the composite index, and the last, corporate social responsibility $10 \%{ }^{26}$

Our final sample is presented in Appendix 2. India provides the largest number of firms with 55 , followed by Taiwan (32), Malaysia (28), Singapore (27), Hong Kong (27), and South Africa (20). Argentina, Colombia, Hungary, Peru, and Poland provide just one firm each. Columns 3-5 present, by country, the mean, median and standard deviation corporate governance score. The average firm in Mexico, Singapore, South Africa, and Hong Kong present with the highest level of corporate governance. In contrast, corporate governance quality tends to be much lower in China, and Indonesia. Finally, the greatest variability in governance scores occurs in Pakistan. In columns 6-11, we present the mean, median, and standard deviation of dividend payouts across countries. Two measures of dividend payout are used, namely dividends-to-cashflow (\%), and dividends-to-earnings (\%). Dividend payouts tend to be highest in Thailand, Singapore, Pakistan, and Hong Kong. The greatest variability in dividend payout occurs in Singapore.

We begin with some summary measures presented in Appendix 3. The analysis is identical to that outlined earlier, but now

\footnotetext{
${ }^{26}$ A potential concern with this measure arises with the inclusion of the social responsibility component, which in itself is unrelated to minority shareholder protection. Since our focus is on estimating the relationship between the strength of minority shareholder protection and corporate dividend payouts, the inclusion of social responsibility appears not to be warranted, at least in the context of this study. Consequently, we re-estimate all subsequent regressions with a revised governance index, which only accounts for the first six components, where each component has equal weight. When we do so, out results remain qualitatively unchanged.
} 
corporate governance is measured using CLSA corporate governance scores. Nevertheless, we tend to reach the same conclusions using both governance measures. Specifically, using the CLSA data, and in line with our earlier findings, we find that for firms with high levels of corporate governance, dividend payout is higher in countries where creditors are well protected, irrespective of the payout measure used. This is consistent with our findings reported in Table 3 where the sales-to-asset ratio is used to proxy corporate governance. When dividends-to-cashflow (\%) is the dependent variable, the difference for the mean (median) dividend payout is $9.31 \%(7.15 \%)$ and the results are statistically significant at the 5\% level. These results again suggest that the ability of shareholders to use their legal rights, here defined at the firm-level, to extract dividends from firms is largely determined by the legal protection afforded to creditors. Where creditors are poorly protected, they substitute poorer protection for lower dividends.

In Appendix 4 we report the results of regression estimates using CLSA corporate governance data. For each of our three measures of dividend payout, we find that corporate governance has a positive effect, in line with our previous findings. When dividendsto-earnings (\%) are used as the dependent variable, the coefficient on corporate governance is 0.335 . Using the same measure for dividends, but now when creditor rights are strong, we find that the coefficient on corporate governance is 0.476 and is statistically significant. Given weak creditor rights, the coefficient estimate is much lower at 0.164 . When dividends-to-cashflow (\%) and dividend payer are used as the dependent variable, the same pattern emerges: when creditor rights are strong, the coefficient on the corporate governance variable is higher. These findings are consistent with those reported in Tables 6 and 7 and confirm our earlier findings. The outcome model of dividends, that is, the ability of shareholders to extract dividends from firms rests largely on the joint impact of the strength of shareholder and creditor legal rights. Where both are strong, dividend payouts tend to be high. When creditors are not so well protected, and even given strong shareholder rights, measured at the firm- and country-level, dividend payouts, and the likelihood of paying a dividend tend to be much lower. In short, creditors exert a greater influence over corporate dividend payout than do shareholders.

\section{Concluding remarks}

In this paper we examine the role of both creditor and shareholder rights in order to ascertain which of these are more important in determining the level and incidence of dividend payouts. Using data for 22,374 firms across 35 countries, we find empirical results in support of the outcome model in countries where creditor rights are strong. When creditor rights are weak, the likelihood of and the dividend amounts are much lower, even when shareholders rights are strong. In turn, we show that the effectiveness of shareholders rights, measured either at the firm- or country-level, is diminished given poor creditor rights. Our results suggest that while creditor rights, shareholder rights, and corporate governance all play a role in determining the likelihood and the level of dividend payouts, creditor rights measured at the countrylevel dominates. We find that the impact of shareholder rights on dividend payouts is weaker when creditor rights are low. In fact, in some specifications, we find that the coefficient estimates on the shareholder rights variables are statistically insignificant, and even negative. Our findings suggest that the outcome model of La Porta et al. (2000) using country-level measures of shareholder rights, and Mitton (2004) using firm-level measures is contingent on strong shareholder and creditor rights. When the latter do not enjoy considerable legal protection, the likelihood of paying a dividend and the dividend amount is much lower.

Our findings differ to Brockman and Unlu (2009) in two crucial respects. First, they show that the number of dividend payers, and the amount of the dividend paid increases in creditor rights. Where creditors are not endowed with sizable legal protection, the number of dividend payers, and the amount of the dividend distributed by those who pay a dividend is much lower. We show that this result prevails, not just when shareholders are not wellprotected, as predicted by the outcome model, but also when shareholders enjoy considerable legal rights, but not so creditors. As a consequence, creditors, and not shareholders, exert the greatest influence over corporate dividend policy. Second, we show that this result prevails even when we measure shareholder rights at the firm and country-level. Finally, our findings add to recent research which highlights the considerable influence that creditors exert on corporate policy.

\section{Appendix 1. Correlation coefficients}

This table presents correlation coefficients for the main variables used in this paper. Dividend payout is measured as either dividends to cashflow (\%), dividends to earnings (\%), or dividends to sales (\%). Revised ADR and the anti-self-dealing index (ASD) are shareholder rights measures from Djankov et al. (2008). Legality is an index of legal development and is measured as the weighted average of Judicial Efficiency, Rule of Law, Corruption, Risk of Expropriation, and Risk of Contract Repudiation (Berkowitz et al., 2003). Investor protection is from La Porta et al. (2006) and is calculated as the weighted average of disclosure, liability standards, and anti-director rights. Rule of law is from La Porta et al. (1998). Creditor rights is from Djankov et al. (2007). Corporate governance is calculated as sales-to-total assets. All information on payout ratios and agency costs is sourced from Worldscope.

\begin{tabular}{|c|c|c|c|c|c|c|c|c|c|c|}
\hline & $\begin{array}{l}\text { Dividends- } \\
\text { to-cashflow }\end{array}$ & $\begin{array}{l}\text { Dividends- } \\
\text { to-earnings }\end{array}$ & $\begin{array}{l}\text { Dividends- } \\
\text { to-sales }\end{array}$ & $\begin{array}{l}\text { Creditor } \\
\text { rights }\end{array}$ & $\begin{array}{l}\text { Revised } \\
\text { ADR index }\end{array}$ & $\begin{array}{l}\text { Self-dealing } \\
\text { index }\end{array}$ & $\begin{array}{l}\text { Investor } \\
\text { protection }\end{array}$ & Legality & $\begin{array}{l}\text { Rule of } \\
\text { law }\end{array}$ & $\begin{array}{l}\text { Corporate } \\
\text { governance }\end{array}$ \\
\hline Dividends-to-cashflow & 1.00 & & & & & & & & & \\
\hline Dividends-to-earnings & $0.798^{* * *}$ & 1.00 & & & & & & & & \\
\hline Dividends-to-sales & $0.482^{* * *}$ & $0.414^{* * *}$ & 1.00 & & & & & & & \\
\hline Creditor rights & $0.212^{* * *}$ & $0.197^{* * *}$ & $0.149^{* * *}$ & 1.00 & & & & & & \\
\hline Revised ADR index & $0.190^{* * *}$ & $0.191^{* * *}$ & $0.117^{* * *}$ & $0.395^{* * *}$ & 1.00 & & & & & \\
\hline Self-dealing index & $0.056^{* * *}$ & $(0.034)^{* * *}$ & $0.134^{* * *}$ & $0.505^{* * *}$ & $0.676^{* * *}$ & 1.00 & & & & \\
\hline Investor protection & $(0.170)^{* * *}$ & $(0.262)^{* * *}$ & $(0.060)^{* * *}$ & $0.127^{* * *}$ & $0.479^{* * *}$ & $0.625^{* * *}$ & 1.00 & & & \\
\hline Legality & $(0.110)^{* * *}$ & $(0.087)^{* * *}$ & $(0.111)^{* * *}$ & $0.180^{* * *}$ & $(0.036)^{* * *}$ & $0.059^{* * *}$ & $0.060^{* * *}$ & 1.00 & & \\
\hline Rule of law & $(0.137)^{* * *}$ & $(0.120)^{* * *}$ & $(0.107)^{* * *}$ & $0.071^{* * *}$ & $(0.196)^{* * *}$ & $(0.018)^{* * *}$ & 0.001 & $0.960^{* * *}$ & 1.00 & \\
\hline Corporate governance & $0.082^{* * *}$ & $0.092^{* * *}$ & $(0.217)^{* * *}$ & $(0.022)^{* * *}$ & $(0.045)^{* * *}$ & $(0.066)^{* * *}$ & $(0.026)^{* * *}$ & $0.074^{* * *}$ & $0.057^{*}$ & 1.00 \\
\hline
\end{tabular}

\footnotetext{
* Significance at the $10 \%$ level.
}

*** Significance at the $1 \%$ level. 
Appendix 2. CLSA Corporate Governance Ratings across countries

This table describes the sample by country. Obs is the number of observations (firms). For each country, we report the mean, median, and standard deviation of firm-level governance, dividends-to-earnings (\%), and dividends-to-cashflow (\%). In the remaining column, we report creditor rights data from Djankov et al. (2007). All firm-level data is sourced from Worldscope. Firm-level governance measures are taken from CLSA (2001).

\section{Appendix 4. Regression estimates using CLSA Corporate Governance Data}

This table reports coefficient estimates from ordinary least squares and logit regressions with heteroscedastic consistent $t$-stats presented underneath in parenthesis. The sample period is 2002. The dependent variable is dividends-to-earnings (\%), dividends-to-cashflow (\%), and dividend payer, as indicated. Separate regressions are reported for the full sample, and for firms who are domiciled

\begin{tabular}{|c|c|c|c|c|c|c|c|c|c|c|c|}
\hline & \multirow[t]{2}{*}{ Obs } & \multicolumn{3}{|c|}{ Corporate governance } & \multicolumn{3}{|c|}{ Dividends-to-earnings (\%) } & \multicolumn{3}{|c|}{ Dividends-to-cashflow (\%) } & \multirow[t]{2}{*}{ Creditor rights } \\
\hline & & Mean & Median & SD & Mean & Median & SD & Mean & Median & SD & \\
\hline Argentina & 1 & 66.70 & 66.70 & - & 0.00 & 0.00 & - & 0.00 & 0.00 & - & 1 \\
\hline Brazil & 16 & 60.74 & 63.90 & 8.78 & 27.67 & 28.43 & 27.52 & 9.47 & 7.29 & 12.41 & 1 \\
\hline Chile & 5 & 60.66 & 59.50 & 3.08 & 31.42 & 40.04 & 17.80 & 13.96 & 14.46 & 10.65 & 2 \\
\hline China & 13 & 47.88 & 49.00 & 9.06 & 34.49 & 44.44 & 23.70 & 23.75 & 27.70 & 17.89 & 2 \\
\hline Colombia & 1 & 57.90 & 57.90 & - & 39.45 & 39.45 & - & 6.13 & 6.13 & - & 0 \\
\hline Hong Kong & 27 & 62.05 & 64.50 & 13.89 & 41.09 & 41.96 & 29.23 & 39.17 & 31.72 & 36.54 & 4 \\
\hline Hungary & 1 & 45.30 & 45.30 & - & 23.11 & 23.11 & - & - & - & - & 1 \\
\hline India & 55 & 56.08 & 53.50 & 10.45 & 30.03 & 23.42 & 23.02 & 21.26 & 16.39 & 18.24 & 2 \\
\hline Indonesia & 14 & 36.07 & 36.05 & 12.51 & 25.21 & 16.80 & 29.04 & 21.70 & 6.61 & 26.31 & 2 \\
\hline Korea & 15 & 44.43 & 43.20 & 4.38 & 13.01 & 10.20 & 13.74 & 5.45 & 4.26 & 5.67 & 2 \\
\hline Malaysia & 28 & 57.00 & 59.45 & 12.67 & 35.89 & 32.85 & 25.53 & 24.70 & 17.96 & 20.97 & 3 \\
\hline Mexico & 5 & 67.86 & 67.10 & 4.96 & 26.39 & 29.39 & 26.58 & 14.39 & 20.54 & 13.32 & 0 \\
\hline Pakistan & 8 & 34.68 & 28.15 & 15.97 & 54.03 & 65.23 & 34.38 & 37.19 & 44.36 & 27.36 & 1 \\
\hline Peru & 1 & 75.50 & 75.50 & - & 46.79 & 46.79 & - & 71.14 & 71.14 & - & 0 \\
\hline Philippines & 13 & 47.36 & 48.80 & 11.87 & 18.50 & 10.57 & 20.48 & 9.34 & 0.00 & 16.15 & 1 \\
\hline Poland & 1 & 34.00 & 34.00 & - & 0.00 & 0.00 & - & 0.00 & 0.00 & - & 1 \\
\hline Singapore & 27 & 67.06 & 64.70 & 7.99 & 45.89 & 36.87 & 43.55 & 35.01 & 23.01 & 38.17 & 3 \\
\hline South Africa & 20 & 67.72 & 66.75 & 9.11 & 26.58 & 28.30 & 26.15 & 19.59 & 10.92 & 21.45 & 3 \\
\hline Taiwan & 32 & 56.70 & 56.90 & 8.40 & 33.32 & 35.56 & 29.86 & 22.08 & 18.86 & 23.18 & 2 \\
\hline Thailand & 13 & 55.32 & 50.10 & 13.00 & 50.96 & 39.85 & 38.30 & 33.88 & 28.48 & 27.49 & 2 \\
\hline \multirow[t]{2}{*}{ Turkey } & 8 & 43.74 & 42.65 & 10.50 & 2.64 & 0.00 & 7.46 & 1.57 & 0.00 & 4.44 & 2 \\
\hline & 304 & 55.87 & 56.7 & 13.49 & 32.23 & 28.98 & 29.35 & 22.71 & 15.81 & 25.44 & \\
\hline
\end{tabular}

\section{Appendix 3. Summary Statistics using CLSA Corporate Governance Ratings}

This table reports summary mean and median (presented in square brackets) payout statistics by level of corporate governance and creditor rights. Corporate governance is measured using CLSA (2001) data. Creditor rights data is from Djankov et al. (2007). Firms are domiciled in countries with high (low) creditor rights if their country level score for creditor rights is equal to or greater (less than) the sample median. The sample median is 2 . A firm has high corporate governance if its governance score is above the sample median. The sample median is 56.7. Dividend payout is measured using either dividends-to-cashflow (\%), dividends-to-earnings (\%), or dividend payer, as indicated. Dividend payer equals one if the firm pays a dividend, zero otherwise. All payout data is sourced from Worldscope.

\begin{tabular}{|c|c|c|c|}
\hline & \multicolumn{3}{|c|}{ Dividend payout measures } \\
\hline & $\begin{array}{l}\text { Dividends-to- } \\
\text { cashflow } \\
(\%)\end{array}$ & $\begin{array}{l}\text { Dividends-to- } \\
\text { earnings } \\
(\%)\end{array}$ & $\begin{array}{l}\text { Dividend } \\
\text { payer }\end{array}$ \\
\hline $\begin{array}{l}\text { High } \\
\text { governance/high } \\
\text { creditor rights }\end{array}$ & $29.71 \%[23.23 \%]$ & $38.81 \%[36.32 \%]$ & $0.857(66 / 77)$ \\
\hline $\begin{array}{l}\text { High } \\
\text { governance/low } \\
\text { creditor rights }\end{array}$ & $20.40 \%$ [16.08\%] & $33.29 \%[34.53 \%]$ & $0.760(57 / 75)$ \\
\hline Difference & $\begin{array}{l}9.31 \% \%^{* *} \\
7.15 \%{ }^{* *}\end{array}$ & $\begin{array}{l}5.52 \\
1.79\end{array}$ & 0.097 \\
\hline
\end{tabular}

in countries with above and below median creditor rights. Also included, but not reported are firm-level controls (size is the log of book assets in US\$, growth is logarithmic one-year asset growth, and profitability is earnings before interest and taxation to book assets), industry and country dummies. Creditor rights is from Djankov et al. (2007).

\begin{tabular}{|c|c|c|c|}
\hline & Full sample & $\begin{array}{l}\text { Above median } \\
\text { creditor rights }\end{array}$ & $\begin{array}{l}\text { Below median } \\
\text { creditor rights }\end{array}$ \\
\hline \multicolumn{4}{|c|}{ Dividends-to-earnings (\%) } \\
\hline Corporate governance & $0.335^{* *}(2.03)$ & $0.476^{* *}(2.02)$ & $0.164(0.77)$ \\
\hline Firm controls & Included & Included & Included \\
\hline Country dummies & Included & Included & Included \\
\hline Industry dummies & Included & Included & Included \\
\hline \#Observations & 304 & 102 & 202 \\
\hline$R$-Squared & 0.229 & 0.296 & 0.271 \\
\hline \multicolumn{4}{|c|}{ Dividends-to-cashflow (\%) } \\
\hline Corporate governance & $0.147(1.06)$ & $0.207(0.98)$ & $0.081(0.47)$ \\
\hline Firm controls & Included & Included & Included \\
\hline Country dummies & Included & Included & Included \\
\hline Industry dummies & Included & Included & Included \\
\hline \#Observations & 282 & 95 & 187 \\
\hline$R$-Squared & 0.282 & 0.303 & 0.321 \\
\hline \multicolumn{4}{|l|}{ Dividend payer } \\
\hline Corporate governance & $0.041^{* *}(2.03)$ & $0.096(1.56)$ & $0.033(1.38)$ \\
\hline Firm controls & Included & Included & Included \\
\hline Country dummies & Included & Included & Included \\
\hline Industry dummies & Included & Included & Included \\
\hline \#Observations & 304 & 102 & 202 \\
\hline
\end{tabular}

** Significance at the 5\% level. 


\section{References}

Acharya, V., Amihud, Y., \& Litov, L. (2009). Creditor rights and corporate risk-taking. National Bureau of Economic Research, Working paper No. 15569.

Adjaoud, F., \& Ben-Amar, W. (2010). Corporate governance and dividend policy: Shareholders' protection or expropriation? Journal of Business, Finance, $\mathcal{E}$ Accounting, 37(5/6), 648-667.

Ang, J., Cole, R., \& Lin, J. (2000). Agency costs and ownership structure. Journal of Finance, 55(1), 81-106

Baba, N. (2009). Increased presence of foreign investors and dividend policy of Japanese firms. Pacific-Basin Finance Journal, 17(2), 163-174.

Bartram, S., Brown, P., How, J., \& Verhoeven, P. (2008). Agency conflicts and corporate payout policies: A global study. Lancaster University, Working Paper.

Benmelech, E., \& Bergman, N. (2011). Vintage capital and creditor protection. Journa of Financial Economics, 99(2), 308-332.

Berkowitz, D., Pistor, K., \& Richard, J. (2003). Economic development, legality, and the transplant effect. European Economic Review, 47(1), 165-195.

Brockman, P., \& Unlu, E. (2009). Dividend policy, creditor rights, and the agency costs of debt. Journal of Financial Economics, 92(2), 276-299.

Brockman, P., \& Unlu, E. (2011). Earned/contributed capital, dividend policy, and disclosure quality: An international study. Journal of Banking \& Finance, 35 , $1610-1625$.

Chae, J., Kim, S., \& Lee, E. (2009). How corporate governance affects payout policy under agency problems and external financing constraints. Journal of Banking and Finance, 33(11), 2093-2101.

Chay, J., \& Suh, J. (2009). Payout policy and cash-flow uncertainty. Journal of Financial Economics, 93(1), 88-107.

Credit Lyonnais Securities Asia. (2001). Saints and sinners: Who's got religion? Published Report.

DeAngelo, H., DeAngelo, L., \& Stulz, R. (2006). Dividend policy and the earned/contributed capital mix: A test of the life-cycle theory. Journal of Financial Economics, 81(2), 227-254.

Denis, D., \& Osobov, I. (2008). Why do firms pay dividends? International evidence on the determinants of dividend policy. Journal of Financial Economics, 89(1), 62-82.

Djankov, S., LaPorta, R., Lopez-de-Silanes, F., \& Shleifer, A. (2008). The law and economics of self-dealing. Journal of Financial Economics, 88(3), 430-465.

Djankov, S., McLeish, C., \& Shleifer, A. (2007). Private credit in 129 countries. Journa of Financial Economics, 84(2), 299-329.

Farinha, J., \& Lopez-de-Foronda, O. (2009). The relation between dividends and insider ownership in different legal systems: International evidence. The European Journal of Finance, 15(2), 169-189.

Gompers, P., Ishii, J., \& Metrick, R. (2003). Corporate governance and equity prices Quarterly Journal of Economics, 118(1), 107-156.

Grullon, G., Michaely, R., \& Swaminathan, B. (2002). Are dividend changes a sign of firm maturity? Journal of Business, 75, 387-424.

Houston, J., Lin, C., \& Ma, Y. (2010). Creditor rights, information sharing, and bank risk taking. Journal of Financial Economics, 96(3), 485-512.

Hu, A., \& Kumar, P. (2004). Managerial entrenchment and payout policy. Journal of Financial and Quantitative Analysis, 39(4), 759-790.
Jensen, M. (1986). Agency costs of free cash flow, corporate finance and takeovers. American Economic Review, 76(2), 323-339.

Jiraporn, P., Kim, Y., \& Kim, J. (2011). Dividend policy and corporate governance quality: Evidence from ISS. The Financial Review, 46(2), 251-279.

Jiraporn, P., \& Ning, Y. (2006). Dividend policy, shareholder rights, and corporate governance. Journal of Applied Finance, 16(2), 24-36.

Klapper, L., \& Love, I. (2004). Corporate governance, investor protection and performance in emerging markets. Journal of Corporate Finance, 10(5), 703728.

La Porta, R., Lopez-de-Silanes, F., \& Shleifer, A. (2006). What works in securities laws? Journal of Finance, 61(1), 1-32.

La Porta, R., Lopez-de-Silanes, F., Shleifer, A., \& Vishny, R. (1998). Law and finance. Journal of Political Economy, 106(6), 1113-1155.

La Porta, R., Lopez-de-Silanes, F., Shleifer, A., \& Vishny, R. (2000). Agency problems and dividend policy around the world. Journal of Finance, 55(1), 1-33.

Mansi, S., \& Wald, J. (2010). Payout policy with legal restrictions. Working paper University of Texas.

McKnight, P., \& Weir, C. (2009). Agency costs, corporate governance mechanisms and ownership structure in large UK publicly quoted companies: A panel data analysis. Quarterly Review of Economics and Finance, 49(2), 139-158.

Mitton, T. (2004). Corporate governance and dividend policy in emerging markets. Emerging Markets Review, 5(4), 409-426.

Nini, G., Smith, D., \& Sufi, A. (2009). Creditor control rights and firm investment policy. Journal of Financial Economics, 92(3), 400-420

O'Connor, T. (2006). Cross-listing in the U.S. and domestic investor protection. Quarterly Review of Economics and Finance, 46(3), 413-436.

Partington, G. (2009). Discussion of an international analysis of dividend payment behaviour. Journal of Business Finance \& Accounting, 36(3/4), 523-529.

Petersen, M. (2009). Estimating standard errors in finance panel data sets: Comparing approaches. Review of Financial Studies, 22(1), 435-480.

Renneboog, L., \& Trojanowski, G. (2007). Control structures and payout policy. Managerial Finance, 33(1), 43-64.

Roberts, M., \& Sufi, A. (2009). Control rights and capital structure: An empirical investigation. Journal of Finance, 64(4), 1657-1695.

Rozeff, M. (1982). Growth, beta, and agency costs as determinants of dividend payout ratios. Journal of Financial Research, 5(3), 249-259.

Sawicki, J. (2009). Corporate governance and dividend policy in Southeast Asia preand post-crisis. European Journal of Finance, 15(2), 211-230.

Setia-Atmaja, L., Tanewski, G., \& Skully, M. (2009). The role of dividends, debt and board structure in the governance of family controlled firms. Journal of Business, Finance, and Accounting, 36(7/8), 863-898.

Shao, L., Kwok, C., \& Guedhami, O. (2009). Dividend policy: Balancing interest between shareholders and creditors. Moore School of Business, University of South California. Working paper.

Short, H., Zhang, H., \& Keasey, K. (2002). The link between dividend policy and institutional ownership. Journal of Corporate Finance, 8(2), 105-122.

Singh, M., \& Davidson, W. (2003). Agency costs, ownership structures and corporate governance mechanisms. Journal of Banking and Finance, 27(5), 793-881. 